\title{
Kazakistan'ın Ulus İnşa Süreci ve Ekonomi Politiği
}

\author{
Aytaç Çağlar*
}

Karabük Üniversitesi, Sosyal Bilimler Enstitüsü, Karabük.

\begin{abstract}
"Kazaklar, birçok defa topyekûn
kırgina uğramak tehlikesiyle yüz

yüze geldi. Fakat hayata bă̆lilık ve

hürriyet aşkıyla, eğik başlarını

doğrultup Allah'ın takdirine umut

bağladilar."
\end{abstract}

-Nursultan Nazarbayev-

$\ddot{O} z$

Bugünkü Türki Cumhuriyetleri, Sovyet Sosyalist Cumhuriyetler Birliği'nin dağılma sinyalleri verdiği 1980'li yıllardan itibaren, ülkelerinde ekonomik reform politikalarn izlemiştir. Bu süreçte yapilan ekonomik reformlar daha çok Sosyalist ekonomi modelinin işleyişinin iyileştirilmesine yönelik olmuştur. Bu reform politikası 25 Aralı 1991'e değin sürdürülmüştür. Bu tarihte, SSCB'nin dağılması ile ardı ardına bağımsızlıklarım ilan eden bu cumhuriyetler, bundan sonraki süreçte ise Sovyet ekonomi modelini terkedip liberal bir ekonomi anlayışını ülkelerinde uygulamaya koymuşlardır. Bu süreçte de Türki Cumhuriyetlerinin revizyonist öncüsü Kazakistan olmuştur. Kazakistan, 16 Aralık 1991'de bağımsızlı̆̆ını ilan ettikten sonra, ulus inşa sürecinde ekonomi politiğgin önemini iyi kavrayan Cunhurbaşkanı Nazarbayev öncülüğünde, büyük bir kalkınma hamlesi içerisine girmiştir. Nazarbayev, piyasalar üzerindeki hükümet kontrolünü tedricen ortadan kaldırarak, serbest pazar ekonomisine geçişin sağlanmasına, devlet işletmelerinin özelleştirerek zengin yeraltı kaynaklarının ülke içinde işletilmesine, iç ve dış pazarın oluşturulmasına, yönelik bir politik ekonomi izlemiştir. Bu amaçlar, yatırımların teşviki kanununun çıkarılması, izlenen fiyat politikaları, vergi ve gümrük konuları üzerine yapılan düzenlemeler ile sahaya uygulanmaya çalışılmıştır. Ayrica 15 Kasım 1993'te milli para birimi Tenge tedavüle sokularak, Rus Rublesinin Kazak ekonomisi üzerindeki etkisi saf dışı bırakılmıştır. İzlenen revizyonist ekonomi politikaları sonucunda Kazakistan ekonomisinde büyük oranda ticari liberalizasyon sağlanmış, tekel kurumlar tasfiye edilmiş, ticaret ve bankacılık sektörleri gelişmiştir. 2017 itibariyle Kazakistan, geleneksel ekonomi ortaklarının yanında, uluslararası ticarette söz sahibi olan yeni aktörlerle de sicak temaslarda bulunarak, dünya ticaretinde aktif rol oynamaktadır. Bu çalışmada, yeni bir disiplin olan Uluslararası Politik Ekonominin temel kavramları üzerinden, Kazakistan siyasi tarihi kısaca tanıtılmış, ertesinde Kazak halkının farklı Rus rejimleri altında milli varlğ̆ın sürdürme mücadelesi ve bu mücadeleyi kazandıktan sonra, ulus inşa sürecinde izlediği ekonomi politikalar değerlendirilmiştir. Çalışmanın temel tezi, Kazakistan'ın bağımsızlıktan sonraki ekonomi politiğinin 2017'ye değgin olan süreçte reel olduğudur.

Anahtar Kelimeler: Kazakistan, Uluslararası Politik Ekonomi, Ulus, Nursultan Nazarbayev.

\section{Kazakhstan's Nation-Building Process and Economic Policy}

\section{Abstract}

Turkic Republics have followed economic reform policies in their countries since 1980s when the Union of Soviet Socialists Republics showed indications of dissolution. During this process, economic reforms rather intended for improving the functioning of the Socialist economy 
model. This reform policy was maintained until 25 December 1991. The republics, declaring their independence one after the other with the dissolution of USSR on this date, abandoned Soviet economy model and adopted a liberal economy understanding in their countries henceforth. During this process, Kazakhstan served as the revisionist leader of the Turkic Republics. Declaring her independence on 16 December 1991, Kazakhstan attempted a substantial move for developing under the guidance of President Nazarbayev who well comprehended the importance of economic policy in the nation-building process. By gradually abolishing the governmental control over the markets, Nazarbayev followed a policy that focused on the transition to the free market economy, the operation of rich underground resources in the country through privatization of government enterprises and the creation of domestic and foreign markets. These objectives were tried to be put into practice through the adoption of law on promotion of investments, price policies followed and regulations in the fields of tax and customs. Furthermore, the effect of Russian Ruble on Kazakh economy was eliminated by mobilizing national currency Tenge on 15 November 1993. As a result of the revisionist economy policies adopted, Kazakhstan economy was commercially liberalized to a great extent, monopolies were liquidated, and trade and banking sectors made progress. As of 2017, Kazakhstan has an active role in the world trade by establishing close contacts with new players involved in international trade as well as her traditional economy partners. This study shortly highlights Kazakhstan's political history through basic concepts of International Political Economy, a newly-emerging discipline, and then evaluates the economic policies adopted during the struggle of Kazakh people to sustain their national existence under different Russian regimes and the nation-building process after their victory. The basic argument of this study is that Kazakhstan's economic policy following her independence has been real up until 2017.

Keywords: Kazakhstan, International Political Economy, Nation, Nursultan Nazarbayev.

\subsection{ULUSLARARASI POLITIKK EKONOMI}

Ekonomi ve politika kavramları literatürde ilk kez "politik ekonomi" ismiyle Aristo tarafından, "devlet giderlerinin karşılanması için vergi konulması" olarak ele alınmıştır. Politik ekonomi Eski Yunancadaki "polis" ve "oikonomike" kelimelerinden türetilmiştir. ${ }^{1}$

Uluslararası Politik Ekonomi, ekonomi ve politikanın birbirinden ayrı değerlendirilmesine tepki olarak doğan bir yaklaşım olarak karşımıza çıkmaktadır. Özellikle de 1970 sonrası dünyada yaşanan gelişmeler karşısında, mevcut analizlerin tek boyutlu kalması, yeni analizlere duyulan ihtiyacı da artırmıştır. ${ }^{2}$ Politika ile ekonomi arasındaki etkileşimi teorik ve metodolojik bir çerçevede açıklamak temeline dayanan bu disiplin, böyle bir ortamda uluslararası ilişkileri realist çerçevede açıklayan yaklaşımlara bir tepki olarak ortaya çıkmıştır. Uluslararası Politik Ekonomi disiplini, ekonomi ve politikanın birbirine üstünlüğünden ziyade birbiriyle eşit derecede etkileşimde olduklarını savunur. ${ }^{3}$ Uluslararası Politik Ekonomi, henüz özgünlüğünü kanıtlayamamış bir disiplin olarak karşımıza çıkmaktadır. Daha çok

\footnotetext{
${ }^{1}$ Davut Ateş, Gülizar Samur Gökmen, “Bir Akademik Disiplin Olarak Uluslararası Politik Ekonominin Sınırları", Afyon Kocatepe Üniversitesi Sosyal Bilimler Dergisi, Cilt 15, Sayı 1, 2013, s. 48.

2 Davut Ateş, Gülizar Samur Gökmen, a.g.e., s. 65.

${ }^{3}$ Arzu Al, "Politika-Ekonomi Kesişmesi: Yeni Bir Bilim Dalı Olarak Uluslararası Politik Ekonomi", İstanbul Gelişim Üniversitesi Sosyal Bilimler Dergisi, Cilt 2, Sayı 1, 2015, s. 144.
} 
iktisat ve uluslararası ilişkiler disiplinlerinin alt dalı olarak ele alınan bu disipline dair kavramsal kullanımlar, son dönemlerde revaçta olsa dahi kavramın tanımı üzerinde kesin bir birliktelik yoktur. ${ }^{4}$ Disiplinin çalışma sahası ise oldukça geniştir; enerji, finans, teknoloji, hegemonya ve uluslararası sisteme etki eden her konu bu disiplinin konusudur. $^{5}$

\subsection{ULUS}

Ulus kavramı üzerinde uzlaşmaya varılmış net bir tanımlama yoktur. Bunun sebebi bu kavramın çok boyutlu ve esnek mahiyetidir. Ulus kavramının kültürel, siyasi, ekonomik, psikolojik boyutlarının kendi alanının uzmanları tarafından, yine kendi alanı içerisinde açıklanması da kavram tanımlamasını zorlaştırmaktadır. Örneğin ABD'li politika bilimci Benedict Anderson, ulusu, "hayal edilmiş bir siyasal topluluk-kendisine aynı zamanda hem egemenlik hem de sınırlılık içkin olacak şekilde hayal edilmiş bir cemaat" olarak tanımlayarak, politik bir açıklama getirirken, İngiltereli sosyolog Anthony Giddens ise ulusu, "bütüncül bir yönetime tabi, hem devlet aygıtının iç unsurları hem de diğer devletler tarafından denetim altında tutulan ve kesin sinırlarla belirlenmiş topraklar üzerinde yer alan bir birlik" olarak toplum bilimsel bir yaklaşımla tanımlamıştır. Bu sınırlılıklar dışında konjönktürel algılamalar da ulus tanımı üzerinde belirleyici rol oynamıştır. Bu bağlamda ulus kavramı ilk olarak toprak temelli tanımlamalara maruz kalmış, 20.yy ilk çeyreğinden itibaren ise dönemsel ihtiyaçlara paralel olarak tanımlamaları da çeşitlenmeye başlamıştır. ${ }^{6}$ Tüm bu bilgilerden hareketle ulus kavramını en genel manada şu şekilde tanımlamak mümkündür: Tarihsel süreçte, kültürel, ekonomik, ruhsal bağlarla bir araya gelmiş, pek çok konuda istikrarlı birliktelik gösteren kolektif bir toplumdur.

\subsection{ULUS DEVLET}

Ulus-Devlet kavramı, feodal sistemin zayif merkezi otoritesine bir tepki olarak, merkeziyetçi bir temelde gelişme gösteren tarihsel bir olgudur. Ulus devletlerin varlığ bir ulusun varlığıyla mümkündür. ${ }^{7}$ Kavram olarak ulus devletten; aynı topraklar üzerinde yaşayan belirli bir ulusun, milli politikalar geliştirerek kendi kaderlerini tayin ettikleri devlet modeli anlaşılmalıdır.

\subsection{ETNISITE*}

Kökenleri eski Yunandaki "Etnos", "Ethnos” (doğum yeri, kavimler, yaşanılan bölge $)^{8}$ kelimesine dayanan etnisite kavramını ilk kez kullanan 1953 yılında ABD’li

\footnotetext{
${ }^{4}$ Davut Ateş, Gülizar Samur Gökmen, a.g.e, s. 46.

${ }^{5}$ Arzu Al, a.g.e., s. 154.

${ }^{6}$ Nurken Aralbekov, Kazakistan Etnik Denge Siyasetinin Temeli Olarak Kazakistan Halk Asamblesi, Gazi Üniversitesi Sosyal Bilimler Enstitüsü, Yayınlanmış Yüksek Lisans Tezi, Ankara 2016, s. 14-15-16.

${ }^{7}$ Bülent Şener, "Küreselleşme Sürecinde Ulus-Devlet Ve Egemenlik Olguları”, Tarih Okulu Dergisi, Yıl 7, Sayı 18, 2014, s. 57.

*Etnisite kavramının etimolojisiyle alakalı geniş bir bilgi için Bkz. Şükrü Nişancı, Cemal Işık, "Etnisite Kavramının İdeolojik Serüveni"

8 Seçil Çam, http://www.tuicakademi.org/etnisite-kavrami/ (E.T. 05.04.2017, 16:20).
} 
sosyolog David Riesman olmuştur. ${ }^{9}$ Kavramın tanımı üzerinde genel bir kabul yoktur. Kavram çeşitli bilim dallarının öznel açıklamalarına konu olmakta ve çeşitli teorilerle açıklanmaya çalışılmaktadır. Genel manada etnisite kavramının kullanımının ise sosyolojik manada ortak köken, akrabalık ilişkileri ve kültürel birliği kastedecek şekilde olduğu anlaşılmaktadır. ${ }^{10}$

\subsection{AZINLIK}

Azınlık kavramının neyi ifade ettiğine dair fikir birliğine varılmış değildir. İkinci Dünya Savaşı sonrası süreçte, "Birleşmiş Milletler İnsan Hakları Komisyonu Ayrımcılığın Önlenmesi ve Azınlıkların Korunması Alt Komisyonu" raportörü Francesco Capotorti'nin 1978'de hazırladığı, "Etnik, Dinsel ve Dilsel Azınlıklara Mensup Kişilerin Haklarına İlişkin Çalışma'sında önerdiği azınlık tanımının kendisinden sonraki hukuki metinlerdeki tanımlamalara referans olduğu görülmektedir. ${ }^{11}$ Caporti, bu raporda azınlığı, "Bir devletin nüfusunun geri kalanına göre sayıca az olan, egemen konumda bulunmayan, o devletin vatandaşı olan, üyeleri nüfusun geri kalanından farklı etnik, dinsel ya da dilsel özelliklere sahip olan ve kültürlerini, geleneklerini, dinlerini ya da dillerini korumaya yönelik, üstü örtülü de olsa, bir dayanışma duygusu gösteren bir grup" olarak nitelendirmiştir. ${ }^{12}$

\subsection{KAZAKLARIN KISA SİYASİ TARİHİ VE RUSLARIN KAZAKİSTAN'I İŞGALİ}

Altınorda Devleti'nin yıkılmasıyla birlikte devletleşme sürecine giren Ruslar, 1552'de Kazan ve 1556'da Astarhan hanlıklarını ele geçirmiştir. Kazaklar ise 1569' da Nogay Hanlığının başkentini kontrol altına almıştır. Sınır ülkeleri arasında istisnasız olarak olumlu yahut olumsuz bir diyalog kurulmasının kaçınılmazlığı realitesine bir de dönem konjüktürünün gerçekleri açısından bakıldığında yeni sınırların, Kazak-Rus anlaşmazlığının başlangıcını oluşturduğu görülmektedir. ${ }^{13}$

Kazaklar, devletleşme çabalarını 15. yüzyılın ortalarında Janibek Han ve Kerey Han'ın önderliğinde Jetisu bölgesinde tamamlamışlardır. Bu devlete zaman içerisinde Türk ve Moğol boyları, Nayman, Celayir ve Dulatların da katıldığı görülmektedir. Kazaklar her ne kadar devletleşme noktasında başarıya ulaşmışlarsa da göçebe yaşam tarzını sürdürmeleri ve neticesinde farklı boyların kendi içerisindeki özerk tutumu, Kazak ülkesinde, devletin devamlılı̆̆ının bir gereği olan siyasi birlikten bahsedilmesini olanaksız kılmıştır. Kazak halkı sosyal yaşamında Urug-Boy-Cüz şeklinde örgütlenmiş olup Cüz'lerde kendi içerisinde Küçük Cüz, Orta Cüz ve Ulu Cüz olmak üzere toplam üçe ayrılırdı. ${ }^{14}$ Bizim dışarıdan bir göz olarak yaptığımız gibi Kazak yöneticileri de bu

\footnotetext{
${ }^{9}$ Ruhtan Yalçıner, "Etnisite ve Milliyetçilik: Eleştirel Bir Değerlendirme”, Ankara Üniversitesi SBF Dergisi, Cilt 69, Sayı 1, 2014, s. 189-215.

${ }^{10}$ Nurken Aralbekov, a.g.e., s. 7-8.

${ }^{11}$ Naz Çavuşoğlu, “Azınlık Nedir", TODAİE İnsan Hakları Yıllığı Dergisi, Cilt 19-20, 1998, s. 93-94.

12 Erol Kurubaş, Asimilasyondan Tanınmaya Uluslararası Alanda Azınlık Sorunları ve Avrupa Yaklaşımı, 2. Baskı, Asil Yayın Dağıtım, Ankara 2004, s. 16.

13 Kürşad Karacagil, “Kazakistan'ın Bağımsızlığının Ayak Sesleri: Almatı Olayları (1986)”, History Studies Dergisi, Cilt: 6, Say1: 1, 2014, s. 101.

${ }^{14}$ M. Savaş Kafkasyalı(Editör), Bölgesel ve Küresel Politikalarda Orta Asya, Ahmet Yesevi Üniversitesi Yayınları, Ankara-Türkistan 2012, s. 390.
} 
kollara ayrılmış yapının yönetimi konusundaki aksaklıkları görmüş ve merkezi otoritenin tesisi için çaba göstermişlerdir* fakat halkı geleneklerinden bir anda koparmanın mümkün olamaması nedeniyle bu yöndeki çabaları Kasım Han zamanına(1145-1523) değin başarısızlıkla sonuçlanmıştır. Kasım Han ile başlayan sistemleşme ve Kazak yükselişi, Hak Nazar Han (Kasım Hanın küçük oğlu,1538$1581)^{15}$ zamanında en üst seviyeye ulaşmıştır. ${ }^{16}$ Hak Nazar Han'dan sonra Hanlığın başına gelen Tevekkel Han(1583-1598) zamanın da Kazak genişlemesi başarılı sayılabilecek bir genişleme göstermişse de ${ }^{17}$ sonraki yıllarda, Kazak ülkesinde, her Kazak kolunun kendi hanlığını kurmak suretiyle birbirlerinden bağımsız yaşadığı sisteme geri dönüldüğü görülmektedir. Kazakların düşmanları tarafından arzulanan ve teşvik edilen bu durum, Kazakların güçlerini azaltarak, Kazak ülkesini düşman istilalarına açık hale duruma getirmiştir. ${ }^{18} \mathrm{Bu}$ istilacıların başını, Moğol asıllı Oyratlar, Kalmuklar, Jurganlar ve diğer taraftan da Ruslar ve Çinliler oluşturmaktadır. ${ }^{19}$

Çarlık Rusya'nın Kazakistan'a olan ilgisi, özellikle de 15-16. asrın ikinci yarısından itibaren artmaya başlamıştır. Rus Çarı IV. İvan, Kazan Hanlıklarından bazılarını ele geçirerek Kazak sınır bölgelerinde muhkem kaleler inşa ettirmiştir. Bu kalelerin çevresinde kısa sürede bir sosyo-ekonomik yapı tesis edilerek, Kazakların gelenekleri tahrif edilmiştir. Böyle bir ortamda Kazak Hanlarının, Rusya'ya karşı Çin'i bir dengeleme aktörü olarak kullandıkları görülmektedir. Fakat 1820'li yıllardan itibaren Çarlık Rusya, Kazak hanlıklarına son verme politikasını devreye koyunca, Kazak Hanlarının denge siyasetinin görece başarısı uzun süreli Kazak çıkarları için yetersiz hale gelmiş ve yeni bir dış politika gerekliliği hasıl olmuştur. Bu gereklilik, Çarlık Rusya'nın Kazak topraklarında hızlı bir sömürü düzenine girişerek asimile çalışmalarını destekleyici yasaları işletmeye koymasıyla daha da belirginleşmiştir. Kazak halkı arasında Çarlık rejimine karşı tepkiler artınca, Abılay Han'ın torunu Kenasarı, halkı örgütleyerek Çarlık Rusya'sına karşı isyan etmiş ve Hanlığını ilan etmiştir. Son Kazak Han'ı olan Kenasarı Han, Rus yayılmasını bir süreliğine geciktirmişse de bir çatışmada öldürülmüştür. ${ }^{20}$ Bundan sonra Kazak ülkesine olan Rus yayılması ve istilacı kavimlerin saldırıları artarak devam etmiştir. Kazaklar dört bir yandan uğradığı istilacı hareketler karşısında küçük başarılar göstermişse de kısa sürede iyice zayıf duruma düşerek bir ölüm kalım cenderesi içinde kalmışlardır. ${ }^{21}$ Kazak bilim adamı Çokan Velihanov bu durumu şöyle ifade etmektedir:

\footnotetext{
${ }^{15}$ Mehmet Saray, Kazak Türkleri Tarihi: Kazakların Uyanışı, Nesil Matbaa Yayıncılık, İstanbul 1993, s. 18.

${ }^{16}$ M. Savaş Kafkasyalı(Editör), a.g.e, s. 23.

${ }^{17}$ Mehmet Saray, a.g.e, s. 19.

${ }^{18}$ M. Savaş Kafkasyalı(Editör), a.g.e, s. 23.

${ }^{19}$ Mehmet Saray, a.g.e, s. 19.

20 Abdulvahap Kara, Okan Yeşilot, Avrasya'nın Yükselen Yıldızı Kazakistan, İstanbul Ticaret Odası Yayinları, İstanbul 2011, s. 31-32-33.

* Kazaklar sirasiyla Kerey Han (1456-1473), Canibek Han (1473-1480) ve Devri Burunduk Han (1480-1511) liderliğinde bir merkezi otorite kurma teşebbüsünde bulunmuşlarsa da bunda başarılı olamamışlardır.

${ }^{21}$ Mehmet Saray, a.g.e, s.20.
} 
"XVIII. yüzyılın ilk dönemleri, Kazak halkı için çok korkunç bir zamandı. Her taraftan Cungar, Idil Kalmukları, Yayık Kozakları ve Baskurtlar, Kazak Hanlı̆̆ııın malın mülkünü istila ederek ailelerini esir olarak götürmüşlerdi." şeklinde ifade etmiştir. 22

Oyratlar, Kalmuklar ve Cungarlar'ın Kazaklara saldırıları öyle bir hal almıştır ki Kazaklar, Rusya'dan yardım istemek zorunda kalmıştır. ${ }^{23}$ Burada vurgulamak gerekir ki varlık-yokluk savaşında Kazaklar, düşmanları içerisinden kötünün iyisini seçmiştir. 1726 ve 1730 yıllarında Küçük Orda Han'ı Ebul Hayr Han, tüm Kazak boylarının hamiliğini üstlenerek, Rus Çarına elçiler göndermiş ve kendilerine gelen yağmacı hareketlere karşı Rusya'nın desteğini istemiştir. Rusya, bu teklifi emperyalist politikalarının bir kolaylaştırıcısı olarak, memnuniyetle karşılamış ve gerekli ilişkilerin tesis edilmesi için Tevkelev adlı elçisini Kazak yurduna göndermiştir. Kazak yurdunda ise Ebul Hayr Han'ı tasdif etmeyen diğer Kazak boyu sultan ve ileri gelenleri olmuştur. Ebul Hayr Han, bu durumu aşmak adına, bazı ileri gelenlere hediyeler sunarak yanına çekmiştir. Tabiki bu noktada Rus elçisi Tevkelev'in de tehditkâr tutumu etkili olmuştur. Netice olarak Rus elçisinin öne sürdüğü şartları, Kazak ileri gelenleri kabul etmek zorunda kalmışlardır. ${ }^{24}$ Tevkelev, bu gelişmeleri derhal amiri Kirillov'a bildirmiş ve Kirillov da Petersburg'a şu raporu yazmıştır:

“...Kazak Hanı ile bazı ileri gelenler Rus hakimiyetine girmeyi kabul ediyorlar. Bövlece Aral Gölü'ne kadar olan yol bize açılmış oluyor. Kazaklara güvenmek güç ise de, Ebu'l-Hayr Han kendi memleketinin yakmnnda bir Rus kalesi yapilmasina müsaade ediyor. Bu bizim için büyük kazançtır. Burayı üs yaparak planlarımızı gerçekleştirebiliriz. Hatta Tanrı'nın yardımı ile Bedahşan'ın zengin topraklarını İran'a ve Hindistan'a kadar adım adım işgal ederek oraların zengin altınlarına, lacivert ve yakut taşlarma sahip olabiliriz. Böylece Jungarlarm daha da kuvvetlenmesini önleyeceğimiz gibi hakimiyetimiz altındaki Başkurtlar, Volga Kalmukları ve daha başkalarının bize karşı birlikte ayaklanma teşebbüslerini de hiç bir askerî kuvvet kullanmadan engelleyebiliriz. Nasıl Kossakların idaremize alınması ile bilinmeyen Sibirya bizim olmuş ve dolayısıyla Çin'e hatta Japonya'ya kadar yayılmamız için yollar açılmış ise Kazakları ve Karakalpakları kontrolümüze aldıktan sonra Orta Asya'yı ele geçirmemiz güç olmayacaktır."

$\mathrm{Bu}$ rapor üzerine Rus Çariçesi Anna İvanova, elçi Tevkelev ve Kirillov'un tavsiyelerini de olumlu karşılayarak Kazak topraklarına en hakim noktada bulunacak olan Orenburg kalesinin Or ile Ural nehirlerinin kesiştikleri yerde inşa edilmesini emretmiştir. ${ }^{25}$ Böylece Kazaklar tedricen Rusya uydusuna alınmıştır. Kazaklar bunu bir koruyuculuk mahiyetinde algilarken Rusya ise tam bir boyun eğdirme şeklinde algılamıştır. İşte bu ikilemler zamanla belirginleştikçe, Rusya baskıcı politikalarını artırmış ve Kazak ülkesindeki asimile politikalarını da etkili şekilde uygulamaya

\footnotetext{
${ }^{22}$ Çokan Velihanov (1985), "Şığarmalar Jinağı", II, Almatı, [Aktaran: Yerkinay Maukhara] (2011), "Siyasi ve Kültürel Açıdan Kazak Hanlığı (1456-1731)”, Konya: Yüksek Lisans Tezi: 63.

${ }^{23}$ Sabri Hizmetli, “Kazak Ulusu ve Kazak Tarihi Üzerine: Dünü ve Bugünü”, İstem Dergisi, Yıl: 9, Sayı: 17, 2011, s. 39

${ }^{24}$ Mehmet Saray, a.g.e, s. 23-24.

${ }^{25}$ Mehmet Saray, a.g.e, s.24- 25.
} 
koymuştur. ${ }^{26} \mathrm{Bu}$ süreç Kazakların Çarlık Rusya'sına doğal bir başkaldırısı şeklinde devam edecektir.

Prof. Dr. Mehmet Saray, Rusya'nın Asya'daki emperyalist hedeflerini, "Rusya'nın Türkistan'da Yayılması" adlı makalesinde şöyle sıralamıştır:

- Altınordu Hanlığı ile olan mücadelelerinde Ruslar, önceleri, kendi sınırlarında ve daima müdafaada kalan taraf durumunda idiler. Fakat Altınordu'nun yıkılmasından sonra kurulan hanlıkların (Kırım, Astarhan, Kazan vb.) zaafları yüzünden sınır boylarındaki mücadelelerde müdafaadan çıkarak saldırgan taraf durumuna gelen Ruslar, neticede, hanlıkların aleyhinde genişlemeye ve oralardaki nüfusu zorla kendilerine bağlamaya başladılar.

- Devamlı harpler Rus hazinesine büyük malî külfetler getiriyordu. Ruslar, boşalan hazinelerini yeni işgal ettikleri yerlerin ahalisinden aldıkları vergilerle doldurma yolunu tutmuşlardır.

- Deli Petro zamanında Ural dağlarında bir maden endüstrisi kurulmuştu. Bu endüstrinin gelişmesi ve iyi bir malî kaynak olabilmesi için, Ruslar, Türkistan'a doğru yayılmak gerektiğine inanıyorlardı.

- Portekizli, Hollandalı ve İngilizlerin yaptıkları gibi Ruslar da İran, Orta Asya, Çin'in hammaddelerini ve Hindistan'ın baharatını satan tüccarlardan biri olmak hayali içinde idiler. Bu hayallerini gerçekleştirmek için de Güney Asya'ya yani Türkistan'a doğru yayılmaları gerekiyordu. ${ }^{27}$

\subsection{KAZAKİSTAN'IN COĞRAFYASI}

Kazak Türklerinin yaşadığı yer manasına gelen Kazakistan kelimesi, 46-87 ile 40-56 kuzey enlemleri arasında, Orta Asya'nın geniş bozkırları ile eski Türk anayurdu Altay'lara kadar uzanan sahayı içine alan bir Türk Cumhuriyetidir. ${ }^{28}$ Kazakistan coğrafi konumu itibariyle Hazar Denizi, Sibirya ve Tanrı Dağları arasında yer almaktadır. Ülkenin Hazar Denizi'ne 1000 km kıyı uzunluğu bulunmaktadır. Kuzeyde Rusya, Doğuda Çin Halk Cumhuriyeti, Güneyde Türk Cumhuriyetleri ve Batı da ise Hazar Denizi bulunmaktadır ve Kazakistan geniş bir yüzölçümüne sahiptir. ${ }^{29}$ Kazakistan'ın Doğu ve Güneydoğusundaki dağlık alan dışında kalan coğrafyasında, ovalar ve bozkırlar yer kaplamaktadır. Memleketin en alçak bölgesini Hazar Denizi sahillerindeki topraklar teşkil eder. Aral ve Hazar arasında yüksek, Üst-Yurt ve Mangışlak ovaları bulunur. Mangışlak'ın kuzeyinde yüksekliği 556 metreye ulaşan, Kara-Tav ve Ak-Tav silsilesi bulunur. Kazakistan ovasının orta kısmi, Turan ovasının bir kısmını teşkil eden kumluk sahadır. Turan ovasının Güneydoğu istikametinden Kara-Tav silsilesi, Sır-Derya ile Çu nehri havzalarını birbirinden ayırır. Doğu

\footnotetext{
${ }^{26}$ Kolektif, Kazakistan Tarihi Makaleler, Türk Tarih Kurumu, Ankara 2007, s.76.

${ }^{27}$ https://www.tarihtarih.com/?Syf=26\&Syz=356235, (E.T 09.04.2017, 18:41).

${ }^{28}$ Mehmet Saray, a.g.e., s. 7.

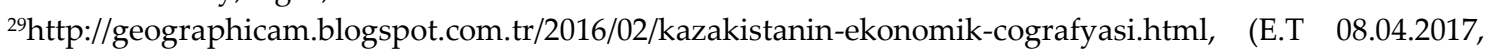
13:44).
} 
Kazakistan ovası daha yüksek olup Balkaş istikametinde alçalır ve güneydoğu istikametinde Tiyen-Şan (Tanrı Dağları veya Han Tengri)'a kadar uzanır. ${ }^{30}$

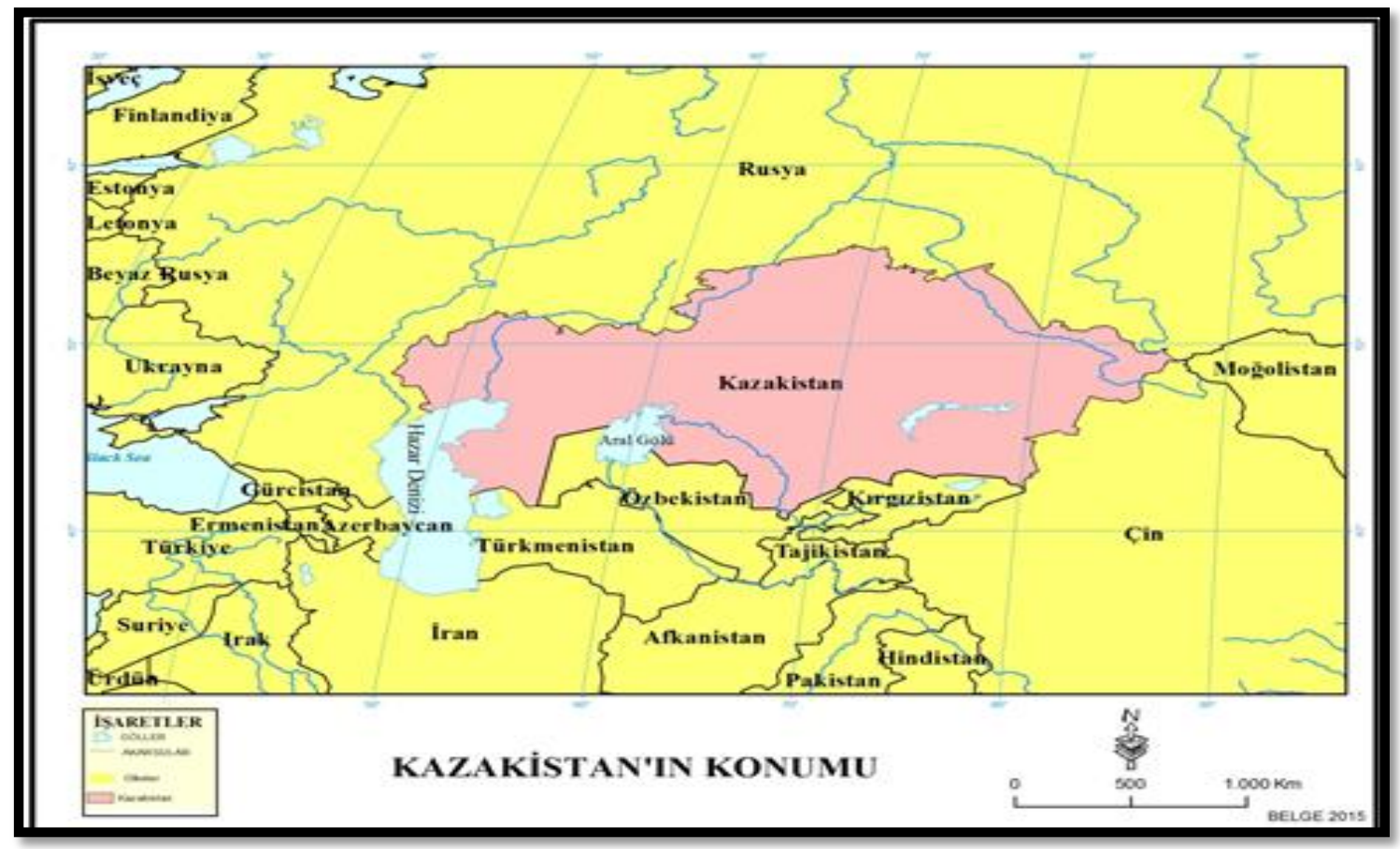

Şekil 1. Kazakistan'ın Coğrafi Konumu

\section{3. ÇARLIK DÖNEMİ KAZAK KIMLİĞí}

Kazakların diplomatik yardım çağrısını, Kazak ülkesine egemen olmak şeklinde kullanmak emelinde olan Çarlık Rusya, bu emelini kısa süre içerisinde tezahür ettirmiştir. Nitekim daha ilk andan itibaren Kazak halkına Rus tebaası gibi muamelede bulunmaya başlamıştır. Özgürlüğüne düşkün olan Kazaklar ise bu durumdan rahatsız olmuşlar ve kendileri açısından zorunlu olan bu birlikteliğe bir an evvel son verme gayreti gütmüşlerdir. Fakat gücü elinde tutan Rusya Kazakların aksine bu bağımlılığ sürdürmek için elinden geleni yapmıştır. Örneğin, Ebu'1-Hayr devrinde Küçük Cüz'e hâkim olan Ruslar, 2 Eylül 1756'da bir tebliğ yayınlayarak Kazakların en verimli otlaklarının bulunduğu bölgelerinden biri olan Ünal'ın sağ yakasına, Kazak Türklerinin ayak basmalarını yasaklamışlar ve yine belirli bir mesafe koyarak, Kazakların Rus askeri mevkilerine yaklaşmalarını da yasaklanmıştır. Yine Ruslar, istemedikleri kişilerin Hanlığını reddedebilmek adına, 1800'den itibaren, seçilen her Kazak Hanı'nın, Rus hükümeti tarafından tasdikini şart koşmaya başlamışlardır. Bundan sonra Rusya kuklası kişiler Kazak Hanı olarak onaylanmış ve Kazakistan'da Hanlık kurumu sadece temsili bir merci olarak varlığını sürdürmüştür. Kazak ülkesini ayağa kaldırmaya çalışacak özverili bir Han ortaya çıktığında ise Rus entrikaları devreye sokuluyor ve bu kişiler bir şekilde ortadan kaldırılıyordu. Rusya tarafından 13 Ağustos 1799'da yayınlanan bir genelge ile Küçük Cüz'de ceza hukuku değiştirilmiştir. $\mathrm{Bu}$ genelge uyarınca suç işleyenleri artık Rus mahkemelerinin cezalandıracağı ilan

\footnotetext{
${ }^{30}$ Mehmet Saray, a.g.e., s. 7.
} 
edilmiştir Orta Cüz bölgesinde ise 1819 'da Veli Han'ın ölümünden sonra, verilen emir gereğince Orta Cüz'de "Han" seçilmesi yasaklanmıştır. 22 Haziran 1822'de Çarlık Rusya, 319 maddelik "Sibirya Kazaklarının statüsünü dair bir yasayı kabul etmiştir. Bu yasaya göre Orta Cüz'de Hanlık yönetimine son verilmiştir ve buranın yönetiminin başına, kendisine "Rus Binbaşısı" rütbesi verilecek yeni bir yönetici verilmesi kararlaştırılmıştır. Böylece Kazak Türkleri, hürriyetlerini ekonomik ve idari yönden kaybetmişlerdir. ${ }^{31}$

Çarlık Rusya, 22 Haziran 1854'te bir ferman yayınlayarak bütün Kazak topraklarını kendi hakimiyetine aldığını ve Kazakların tamamıyla Rus kanunlarına tabi edildiğini ilan etmiştir. Bu kanunun yayınlanmasından kısa süre sonrada Çar I. Nikola, Rus göçmenleri, Kazakların yurduna yerleştirerek bölgenin demografik yapısını Kazaklar aleyhine-suni olarak bozmuştur. ${ }^{32} \mathrm{Bu}$ müdahale farklı asimilasyon unsurlarıyla da birleşince 1865'e gelindiğinde Kazakistan'ın en önemli şehir merkezleri olan Akmescit, Tokmak, Piskek, Jumğol, Kurtka, Türkistan, Simkent ve Taşkent Rusların eline geçmiştir. Ruslar, bu şehirlerde bulunan Kazak toplumuna ait askeri kaleleri, dini mekânları, Kazak kültürünü yansıtan çeşitli yapıları tahrip etmişler, Kazakların mallarına el koymuşlar ve kendilerine direniş gösterenleri de öldürmüşlerdir. ${ }^{33} \mathrm{Bu}$ Kızıl esaret karşısında milli refleksleri giderek güçlenen Kazaklar, 1916'da Çarlık Rusya'ya karşı isyan etmişlerdir. Kazakların bu isyanına bir de 1917'de Rusya halkının, yolsuzluk, kötü ekonomi gibi sebeplerle Çarlık rejimine karşı Bolşevik ihtilalini yapması eklemlenince, Çarlık otokrasisi yıkılmış ve Kazakistan'da bundan istifade ederek 1917'nin Aralık ayında muhtariyetini ilan etmiştir. Fakat 1919 senesinde Kızılordu Kazakistan'1 işgal ederek 20 Ağustos 1920'de Kazak Özerk Sovyet Sosyalist Cumhuriyeti'ni kurmuştur. ${ }^{34}$ Bundan sonraki dönemde de Çarlık rejiminin emellerinden çokta farklı olmayan asimilasyon politikalarına tabi tutulan Kazakistan, bilim ve teknikte Rusya ile yarışamayacağını anlamıştır. Bu bakımdan 19.yy sonlarından itibaren Rusya'ya karşı silahlı mücadele yürütmekten çok ilmi ve kültürel yönden kendisini geliştirmeyi tercih etmiştir. ${ }^{35}$ Kazakistan'ın bu realpolitik tavrı, bağımsızlığına giden süreci kısaltmış ve Sovyet Rusya'nın yumuşak güç unsurlarına da etkili bir cevap olmuştur.

\subsection{SOVYET DÖNEMİ KAZAK KİMLİĞí}

1917 Ekim Devrimi sonrasında kurulan SSCB, Çarlık Rusyası'nın Kazakistan'a yönelik politikalarını küçük farklılıklarla devam ettirmiştir. Bu farklılık, iki rejimin Kazak halkının dini ve sosyal yapısına yönelik tahayyüllerinde belirginleşmiştir. Çarlık Rusya'sından farklı olarak, Bolşeviklerin temel amacı Ortodokslaştırma değil, Sovyetleştirme, Sovyetik-ateist bir ulus oluşturmaktır. Bu bağlamda ulaşılması istenen nihai hedef "Birliği oluşturan halkların her birinin kendi ulusal kimliğini bir kenara

\footnotetext{
${ }^{31}$ Mehmet Saray, a.g.e., s. 29-32.

${ }^{32}$ Mehmet Saray, "Kazakistan”, Türkiye Diyanet Vakfı İslam Ansiklopedisi, Cilt 25, Ankara 2002, s. 121-125.

${ }^{33}$ Ali Kafkasyalı , "Bağımsızlıklarının 20. Yılında Kazakların İstiklal Mücadelesi Tarihine Bir Bakış”, Türk Dünyası Incelemeleri Dergisi, Cilt 12/1, 2012, s. 176.

${ }^{34}$ Mehmet Saray 2002, a.g.e., s. 121.

${ }^{35}$ M. Savaş Kafkasyalı (Editör), a.g.e., s. 391.
} 
bırakıp, Sovyet üst kimliği altında birleşip, Sovyet halkını oluşturmalarıdır. ${ }^{36}$ Fakat bunu yaparken aynı zamanda da Türk toplulukları arasındaki bazı farklılıklar derinleştirilerek, Türk topluluklarına, farklı kimlikler oldukları telkin edilmiştir. ${ }^{37}$ SSCB bunu yaparken, demokratik bir hava yaratmaya çalışarak halkların gözünde meşruluk sağlamaya gayret etmiştir. Fakat bu demokrasi maskesi kısa sürede düşmüş ve Kazak dilinii, tarihini, kültürünü, nüfusunu, dinini yozlaştırma, tahrif ve tahrip etme haline dönüşmüştür. Burada belirtmek gerekir ki SSCB'nin bu politikası çok hassas temellere dayalıdır ve sonuçları itibariyle de kısa vadede SSCB adına başarılı sonuçlar verdiği görülmektedir. Ancak ilerleyen süreçte bu yumuşak güç unsurlarına karşı, Kazak toplumunun aynı şekilde irade geliştirmesi, mutlak bir milli şuur kaybının önüne geçecektir. Fikri temelleri henüz Çarlık döneminde Nikolay İlminski tarafından atılan Türk lehçeleri arasındaki farklılıkları çoğaltarak, Türkler arasındaki dil birliğine mani olma politikasını SSCB de devam etttirmiştir. Ayrıca, Sovyetler, Türkiye Türkçesi'nde geçen islami kelimelerin de kullanılmasını yasaklamış ve bunların yerine Rusça kelimeler kullanılmasını istemiştir. Sovyetlerin ikinci müdahalesi alfabe konusunda olmuştur. Kazakistan'da 1920'li yillarda Arap alfabesi yasaklanmış ve Latin alfabesine geçilmiştir. $^{38}$ Yeni alfabe alınırken, biraz evvel bahsedilen Sovyet politikası gereği, Türk lehçelerine uygulanan alfabelerin bazı noktalarda birbirinden farklı olmasına özellikle dikkat edildi. ${ }^{39}$ Devam eden yıllarda Sovyetlerin dil konusundaki kanunları peşpeşe gelmiştir.1921 yılında resmi yazışmaların Rusça olarak yapılması kararı çıkarılmış, 1938 yılında Kazak okullarında Rus dilinin öğretilmesi zorunlu hale getirilmiştir. Kazak tarih ve kültürü üzerine yapılan araştırmalar ise Rusça metinlere çevrilerek Kazak toplumuna sunulmuştur. Kuvvetle muhtemel çeviriler sırasında orijinal metinler tahrifata uğratılmıştır. 1939 yılında yeniden alfabe değiştirilerek Kiril alfabesine geçilmiştir. Dilin bir millet için ne denli önemli olduğunu bilen Kazak Türk aydınları, milli dil sahasında sistemli çalışmalara girişmişlerdir. Dostum Olcas Süleyman'ın önderliğini yaptığı bu Kazak aydınlar grubu, yazdıkları çeşitli türdeki eserleriyle, Kazak dilini Rusça, Kazak tarihini ise Rus tarihi karşısında diri tutmaya çalışmışlardır. ${ }^{40}$ Olcas Süleyman, yazılarında kendi milletinin geçmişine, kültürüne duyduğu hasreti şöyle ifade ediyor:

"Yaşllar! Ben şehirlerimin nasıl mahvolduğunu bilmek istiyorum. Ben, birç̧ok milletlerin tarihini biliyorum. Şimdi de Kazakların tarihini öğrenmek istiyorum" ${ }^{41}$

Diline sahip çıkarak halkı bilinçlendirmeye çalışan Kazak Türk aydınlarına Sovyetler tarafından, "gerici pantürkist-panturanist" hareketler damgası vurularak yaptıkları iş bir suç olarak değerlendirilmiştir. ${ }^{42}$ Buraya kadar olan kısımda SSCB

\footnotetext{
36 Turan, Aslihan P., “Orta Asya'da Dönüşüm”, http://www.bilgesam.org/incele/1059/-ortaasya\%E2\%80\%99da-donusum/\#.WSA2EOvyjIU (Erişim Tarihi: 20.05.2017).

37 Erol Kurubaş, “SSCB Sonrası Türki Cumhuriyetlerinde Yeni Uluslaşma Süreçleri Üzerine Bir Değerlendirme", Uluslararası Hukuk ve Politika Dergisi, Cilt. 2, Sayı 5, 2006, s. 119.

${ }^{38}$ Mehmet Saray, a.g.e., s. 93-108.

${ }^{39}$ Samet Agaoğlu, Sovyet Rusya İmparatorluğu, Baha Matbaası, İstanbul 1967, s. 42.

${ }^{40}$ Mehmet Saray, a.g.e., s. 108.

${ }^{41}$ B.Rıza, “Kazakistan'da Milliyetçilik”, Dergi, 41, 1965, s. 50-51.

${ }^{42}$ Mehmet Saray, a.g.e., s. 108.
} 
döneminde Kazak dilinin, Rusça'ya tedrici olarak evriltildiği sonucu çıkmaktadır. Kazak toplumunun, SSCB'nin bu politikalarına karşı nasıl refleksler geliştirdiği ise bu çalışmanın "Ulus İnşa Çabaları" başlığı altında detaylıca ele alınacaktır.

SSCB, Kazak dilinin yanında Kazakistan'ın dini yapısını da Sovyetleştirme politikası açısından tehlikeli bulmuştur. Çünkü Orta Asya Türklerinin bu inanç sitemi etrafında SSCB'ye karşı birleşmelerinden korkuluyordu. Aynı zamanda da İslam dininin öğretileri SSCB'nin siyasi ideolojileriyle örtüşmemekteydi. Orta Asya coğrafyasında en fazla Müslüman nüfusa sahip ülke olan Kazakistan'da, SSCB yönetiminde dini okullar, camiler ve Kuran kursları kapatılarak bu kurumlarda çalışan kişiler sürgüne gönderilmiştir. ${ }^{43}$ Aynı zamanda da İslam inancının gerektirdiği uygulamaların tatbikine engel olunmuştur. Bu uygulamaların, Kazak Türklerinin azınlıkta kaldıkları, Rusların ise çoğunlukta bulundukları Kuzey ve Batı Kazakistan'da büyük etkiler yarattığı görülmektedir. Öyle ki buralarda yaşayan Müslüman Kazak Türkleri, İslami uygulamalardan büyük ölçüde kopmuşlardır. Bu kampanyalar ile Sovyetlerin maksadı daha evvel de ifade edildiği üzere Sovyetik-ateist bir toplum yaratmaktı. Bunu sadece islami kurumları yasaklayıp islami akidelerin ifasına engel olmakla yapmayan SSCB, 1948-1955 arasında 126 çeşit din aleyhtarı kitabı Kazak Türkçesi'nde basıp halka dağıttırmıştır. Yine SSCB, Kazakistan ve diğer Türk Cumhuriyetleri'nde inanç özgürlügünün sağlandığına işaret eden, tamamen diş propagandaya yönelik, sahte bilgilerle dolu kitaplar ve dergiler yayınlatmıştır. ${ }^{44}$

I. Dünya savaşının etkileri, 1916'da patlak veren Kazak milli ayaklanması ve ertesinde yaşanan 1917 ihtilali ve 1919'da Kızılordunun Kazakistan'ı tekrar işgali, 1920 kışının uzaması gibi durumlar Kazak halkını bitkinliğe ve açlıktan ölme noktasına getirmiştir. SSCB hükümeti ise halkın bu durumunu sonlandıracak etkin bir karar almamıştır. ${ }^{45}$ Kazak halkının içine düştüğü zor durumu Zeki Velidi Togan şöyle ifade etmiştir:

"Ölen ahali hep Kazaklardı bundan başka Rus hükümetinin ve bilhassa Bolşeviklerin, yerli ahalinin sihhatine hiç ehemmiyet vermemeleri, hatta bazen kasti olarak ihmal etmeleri yüzünden ölümler çoğalıyordu."46

Ne var ki Kazakların kırılması Sovyet çıkarlarına da zarar vermeye başlayınca, SSCB hükümeti, 1921-1925 arası dönem için planlanan ekonomik tedbir politikasını almak zorunda kaldılar. Bu tedbir politikasının temel hedefi, halkın ekonomik durumunun kesinlikle düzeltilmesidir. Kazak halkının en iyi bildiği ve dolayısıyla Kazak ekonomisi üzerinde belirleyici olan şeyler tarım ve hayvancılık olduğundan, Kazak halkı bu süreçte bu sahalara yönelmiş ve bu yolla refaha ulaşmaya çalışmıştır. Fakat Kazak topraklarının ve otlaklarının en verimli bölgeleri Rus göçmenleri ile Kossaklara verildiği için Kazak Türkleri ellerindeki verimsiz topraklarda ziraatçllık ve

43 Lazzat Auyessova, Kazakistan'da Sovyet Siyaseti, İstanbul Üniversitesi Sosyal Bilimler Enstitüsü, Yayımlanmamış Yüksek Lisans Tezi, 2010. s. 134-143.

${ }^{44}$ Mehmet Saray, a.g.e., s. 105-106.

${ }^{45}$ Mehmet Saray, a.g.e., s. 96.

${ }^{46}$ Ahmet Zeki Velidi Togan, Bugünkü Türkili, İbrahim Horoz ve Güven Basımevleri, İstanbul 1942, s. 381. 
hayvancılık yapmak zorunda bırakılmıştır. Neticede ise Kazak ekonomisi tabiri caizse Kazak halkını ancak öldürmeyecek kadar bir düzelme göstermiştir. SSCB daha sonra Kazak ekonomisini tam olarak kontrol edebilmek adına 1925-1929 arasında yürüteceği Kazak ekonomisini devletleştirme politikasını devreye sokmuştur. Bu süreçte, daha önce ifade edildiği üzere Kazakların temel geçim kaynağı olan toprakların ve hayvanların devletleştirilmesi politikası izlemiştir. Bu süreç genel olarak, kooparatifler kurmak, Kazak halkının elindeki hayvanlara el koymak şeklinde ilerletilmiştir. Fakat SSCB'nin altyapısı eksik olarak ortaya atttığı-sakat doğan Sovyetleştirme politikası, aynı basiretsizliği yürütme konusunda da göstermiş ve Kazak halkına zulümden öteye geçememiştir. Bu menfi gelişmeler üzerine Stalin, 1929'da, yaptığı bir açıklama ile gerekli hazırlıklar yapıldıktan sonra devlet çiftliklerinin kesinlikle kolhoz şekline dönüştürüleceğini belirtmiştir. Fakat Stalin'in açıklamasından kısa süre sonra yeni bir örgütlenmeye gidilmeden Kazak halkı zorla kolhozlaşmaya sokulmaya çalışılmıştır. Kolhozlaştırma, şu dört aşamada gerçekleştitilmiştir: 1929-1930, 1930-1932, 1932-1934, ve 1934-193877 Denilebilir ki kolhozlaştırma politikası, Sovyet rejiminin temelsiz asimile ve resmi soykırım politikalarından biri olarak Sovyet utanç tarihinde yerini almıştır.

SSCB’nin Kazak Türklerine karşı izlediği politikalar karşısında, Kazak aydınları Moskova'yı protesto ederek bu politikaların değiştirilmesini talep etmişlerdir. Sovyet yönetimi ise protest hareketlere öncülük edenleri "Burjuva milliyetçiliği" ile itham etmiş ve bir süre sonrada bu isimler bazen resmi olarak bazen de faili meçhul olarak bir bir ortadan kaldırılmıştır. Örneğin, Alaş Orda liderlerinden Alihan Bukeyhan'ı 1932'de, Ahmed Baytursun'u 1937'de ve onların hükümetinde vazife görmüş Bakan arkadaşları Muhammedcan Tınışbay'ı 1936'da, Halil Dostmuhammed'i 1937'de ve "Uyan Kazak" şiirinin ünlü şairi Mir Yakub Dulat'ı da 1937'de idam etmişlerdir. II. Dünya savaşı yaklaşırken, Sovyetler savaşa hazır ordu bulundurulması için, Kazak Türklerini askere almıştır. Savaş başladıktan sonra ise Sovyet madenlerinin çoğunun Almanya'nın işgali altına girmesi nedeniyle, Sovyetler gözlerini Kazakistan madenlerine dikmiştir. Kazakistan'ın yeraltı kaynaklarını işleten Sovyetler, işçi gücünü de yine Kazak Türklerinden temin yoluna gitmiştir. Öyle ki bu madenlerde ve Sovyet kolhozlarında yaşları 10 ila 15 arasında değişen Kazak çocuklarının, kadınların çalıştırıldığı görülmektedir. Cephede SSCB adına savaşan Kazak Türklerinin de yarısına yakını ülkelerine geri dönememiş ve böylece Kazakistan nüfusu hem cinsiyet dağılımı açısından hem de Rus-Kazak etnik dağılımı açısından bir kez daha Kazakistan aleyhine bozulmuştur. SSCB'nin bundan sonra da korunaklı bir jeopolitiğe sahip olan Kazakistan'da, askeri endüstrisini geliştirme politikası izlediği görülmektedir. SSCB'nin, Kazakistan'ın yeraltı zenginliklerinden, işçi gücünden, jeopolitiğinden faydalanmak politikalarının dışında, bir diğer büyük atılımı da Stalin'in ölümüyle beraber yerine gelen Nikita Kruşçev yapmıştır. $O$, tarımı yaygınlaştırmak adına "Virgin Lands" (Bakir Topraklar) projesini ortaya atmış ve çoğu Kazak Türklerinden oluşan bir milyona yakın insan, çok ağır şartlarda çalıştırılarak, 25 milyon hektarlık bir alanı ziraat yapılır hale getirmiştir. Ayrıca bahsi geçen bölgede yer alan tarihi Kazak şehri

\footnotetext{
${ }^{47}$ Mehmet Saray, a.g.e., s. 96-98.
} 
Akmolla'nın adı Zeliograd olarak değiştirilmiştir. ${ }^{48}$ Kazakistan topraklarının büyük çoğunluğunun tarıma açılmasıyla Kazak ülkesine her zamanki gibi yüzbinlerce Rus ve Ukraynalı çiftçi göç ettirilmiştir. Öyleki 1959 yılına gelindiğinde Kazaklar, kendi ülkelerinde azınlık durumuna düşmüşlerdir. Bu tarihte Kazakistandaki Kazakların nüfussal oranı \%30, Rusların ise \%43'tür. ${ }^{49}$ Burada belirtmek gerekir ki SSCB'nin Kazakistan'1 asimile etmek için geliştirdiği her politika, uygulama sahasına döküldükçe SSCB'nin Kazakistan'a olan bağımlılığını her defasında arttırmıştır. Kısa vadede SSCB için başarılı sayılabilecek olan bu politikalarının pek çoğu ilerleyen süreçte Kazakistan'ın yükselmesinde önemli rol oynamıştır.

SSCB'nin Kazak halkını Sovyetleştirme çabaları, dil alanında olduğu kadar kültür alanında da kendini hissettiriyordu. SSCB yönetiminde, Kazak milli ruhunu körükleyecek yapıtların yayınlanması yasaklanmış, Kazak edip ve şairlerine "proletarya ve kolhoz edebiyatı" yaratılması için telkinlerde bulunulmuştur. Kazak ediplerinden, konu olarak, “Büyük Kardeş” Rusya'nın, kendilerine olan yardımlarını işlemeleri istenmiştir. ${ }^{50}$ Sovyetlerin kültür sahasındaki bu müdahalesine karşı Kazak aydınları da boş durmamış ve özellikle de Türk Cumhuriyetlerinin müşterek kültür adamları olan "Dede Korkut" "Manas", Ali Şir Nevai, Uluğ Bey, Ahmed Yesevi ve Mahdum Kulu gibi simgesel kişiler üzerine çalışmalar hızlandırılmıştır. ${ }^{51}$

7 Eylül 1953'te Kruşçev, SSCB'nin başına geçtikten sonra ilk verdiği direktiflerden biri de Sovyet tarihçilerinin toplanması olmuştur. Böylece 1954'de Özbekistan-Taşkent'de "Sovyet Tarihçileri Konferansı" toplanmıştır. Bu konferansta, Türklerden daha önce milli tarihleri ile ilgili yazdıkları hususları inkar etmeleri istenmiştir. ${ }^{52}$ Moskova'nın direktifi ile konferansa ev sahipliğini yapan Özbekistan Komünist Partisinin Merkez Komite I. Sekreteri Reşidov, Konferansa katılan tarihçilere şu hususlara dikkat etmelerini söylemiştir:

"Daha Önceleri Rusya'da esir durumunda yaşamış olan milletlerin mutluluğu şu ki, onlar Ruslarla bir arada, Rusların kardeşçe yardımı sayesinde, dahi Lenin tarafindan çizilmiş yol üzerinde yürümüşlerdir... Komünist Partisi tarafından yönetilen Rus milleti, ülkemizin bütün halkların tek bir kardeş aile halinde birleştiren bir kuvvet olmuştur. Rus milleti, bütün Sovyetler Birliği halklarının derin bir saygısını kazanmıştır. Bunun içindir ki bu halklar, haklı olarak onu ağabey diye antyorlar". Reşidov sözüne devam ederek, "bilimsel eserlerde panislamizm, panturkizm, ceditcilik ve başka burjuva nasyonalism ve ihtilal aleyhtarı akımlarm irticai mahiyetini meydana koymak gerekmektedir" demiştir. ${ }^{53}$

Tarih yazıcılığı hakkında Taşkent Konferansı'nda Reşidov'un ağzından dile getirilen Komünist Partisi'nin görüşleri, 8 sene sonra- 18-21 Aralık 1962'de Moskova'da

\footnotetext{
${ }^{48}$ Mehmet Saray, a.g.e., s. 101-103.

${ }^{49}$ Gürbüz, Y. Emre, “Kazakistan'da Bir Ulus Devlet Kurmak”, Praksis Dergisi, 11, 2004, s. 208.

${ }^{50}$ Mehmet Saray, a.g.e., s. 108-109.

${ }^{51}$ P. Urban, “Türkistan Sovyet Cumhuriyetlerinde Milli-İdeolojik Eğilimler”, Dergi, 23-24 (1961), s. 47.

${ }_{52}$ Mehmet Saray, "Rus Tarih Araştırmalarında Türkmenistanın İşgali”, Türk Kültürü Araştırmaları, Ankara 1986, s. 85-92.

${ }^{53}$ P. Urban, “Sovyet Milli Siyasetinin Bugünkü Eğilimleri”, Dergi, 35-36 (1964), s. 80.
} 
toplanan Sovyet Tarihçileri Konferansı'nda yeniden ortaya atılmıştır. Sovyet Komünist Partisi Sekreterlerinden B.N. Ponomaryov, yaptığı açılış konuşmasında Sovyet tarihçilerine şu hususları hatırlatıyordu:

"Sovyet tarihçisi, geniş tarihi perspektifi hesaba katmalıdır. Bu ışık altında objektif olarak, kendi milletlerinin Rus milletiyle yakınlı̆̆ıın ve Rusya ile birleşmelerinin olumlu manasını ortaya koymaya ve açıklamaya çalı̧acak olan Sovyet Cumhuriyetleri tarihçilerinin bu gayretleri, her türlü yardıma hak kazanmış olacak ve bu yardımı görecektir. Bazı halklar için zamanında Rusya ile birleşmek, doğrudan doğruya fiziki imhadan kurtulmak için yegane yoldu. Ayrı ayrı cumhuriyetler tarihinin, bütün memleket tarihinin bir parçası gibi aydınlatılması lazımdır." 54

$\mathrm{Bu}$ konuşmadan anlaşılacağ 1 üzere SSCB, kendi tarihçilerinden, Rus olmayan milletlerin tarihlerini, Sovyet çatısı altında birleştirecek bir vizyon geliştirmelerini, Rus olmayan halk için Rusya'nın tek kurtuluş yolu olduğunun benimsetilmesini istiyor, eğer böyle olursa Sovyet hükümetinin maddi olanaklarını sonuna kadar kendilerine sağlayacağını vaad ederek bu şuurda çalışmaya teşvik etmiştir.

SSCB'de Gorbaçov'un iktidarı yıllarında konjonktürel bir zorunluluk olarak başlattığı Glastnost ve Perestroyka politikaları ile SSCB güdümlü katı tarihçilik yazımındaki baskılar azalmış ve Sovyetlerde yaşayan, Rus olmayan halkların milli tarih yazıcılığı daha gerçekçi hale gelmiştir. ${ }^{55}$ Bütün bunlar göz önüne alındığında, Bolşevik Devrimi sonrasından başlayıp SSCB'nin dağılmasına kadar uygulanan "Homo Sovieticus" politikaları kapsamında Türk topluluklarının farklılıkları pekiştirilerek Sovyet üst kimliği etrafında kendi kültüründen soyut bir Kazak halkı yaratılmak amaçlanmıştır demek mümkündür. ${ }^{56}$ Bu manada hem Çarlık Rusya'nın hem de Bolşeviklerin Kazakistan'a bıraktığı miras, yönetimde "Sovyet insanı (Soviet man) denilen ve kendini Sovyet hedeflerine adamış yeni bir insan modeli oluşturma çabalarının, ruhu öteleyerek ekonominin ihtiyaç duyduğu kalifiye elemanları yetiştirmek amacında olan eğitimin, sistem için insan düşüncesinin, farklılıkların sürtüştürülme politikasının yoğun izlerini taşımaktadır. ${ }^{57}$ İşte bu miras, şartlar olgunlaşıp bağımsızlık kazanıldıktan sonraki süreçte-ulus inşa sürecinde, Kazakistan'ın mutlaka reddetmesi gereken bir miras olarak karşısına çıkmıştır.

\subsection{BAĞIMSIZ KAZAKISTAN DEVLETINIIN KURULMASI}

1980'li yılların sonunda Sovyet sistemi ve ekonomisi hızlı bir çöküş sürecine girmiştir. Sovyetlerdeki bu istikrarsız yapı, Kazakistan'daki istikrarı beraberinde getirmiştir. Bu durumu fırsata çeviren Kazakistan, 24 Nisan 1990' da Kazakistan Yüksek Sovyeti, Kazak Devlet Başkanlığı makamını tesis etmiştir. Meclis 'te yapılan gizli oylamada Kazakistan'ın ilk Devlet Başkanı olarak Nursultan Abişulı Nazarbayev

\footnotetext{
${ }^{54}$ P. Urban, a.g.e, s. 80.

${ }^{55}$ Mehmet Saray, a.g.e., s. 113.

56 Ayan, Ergin, "Kafkasya ve Türkistan'da Ulus Devletler Sistematiğinin Oluşma Süreci”, ODÜ Sosyal Bilimler Enstitüsü Sosyal Bilimler Araştırmaları Dergisi, Cilt 2, Sayı: 3, 2011. s. 11

${ }^{57}$ Ahmet Sağlam, "Sovyet Kimliği ve Sürekliliği", http://www.turkdod.com/2012/05/02/sovyet-kimligi-vesurekliligi/ E.T: 05.05.2017, 13.54.
} 
seçilmiştir. 25 Ekim 1990'da Kazakistan Yüksek Sovyeti, Kazak Sovyet Sosyalist Cumhuriyeti'nin siyasi egemenliğini ilan etmiştir. Kazakistan Cumhurbaşkanı Nazarbayev, bunu bağımsızlık yolundaki ilk önemli adım olarak değerlendirmiştir. Yine Kazakistan'ın bağımsızlığından sadece 74 gün önce yani 2 Ekim 1991 'de Sovyetler Birliği'nin Kazakistan topraklarında bulunan Baykonur Uzay Üssünden, Kazak astronot Toktar Ebubekirov uzaya gönderilmiştir. Bağımsızlık emareleri olarak yorumlanabilecek bu gelişmeler ardı ardına gelirken, 1 Aralık 1991'de Kazakistan'da ilk defa devlet başkanlığı için halk oylaması yapılmış ve N. Nazarbayev, oyların \%98,7'sini alarak Kazakistan'ın halk tarafından seçilen ilk devlet başkanı olmuştur. Seçimlerden 10 gün sonra Kazak Parlamentosu, ülkenin adından "Sovyet Sosyalist" ibaresinin çıkarıldığı ve devletin resmi adının "Kazakistan Cumhuriyeti" olduğunu ilan etmiştir. Sovyetler Birliği'nin çözülmesini engellemek isteyen Komünist Partisi, Sovyet Sosyalist Cumhuriyetler Birliği'nin gizli istihbarat servisi KGB ve Kızıl Ordu'nun tutucu güçlerinin, 19 Ağustos 1991 'de Moskova'da, Mihail Gorbaçov yönetimine karşı başarısız darbe girişiminde bulunmasından sonra, Rusya Federasyonu dahil tüm birlik cumhuriyetleri Sovyetlerdeki bu iç karışıklıktan istifade ederek birbiri ardına bağımsızlıklarını ilan etmiştir. Kazakistan da 16 Aralık 1991'de bağımsızlı̆̆ını ilan etmiştir. Bağımsız Kazakistan'ı, Türkiye en başta olmak üzere birçok devlet kısa süre içerisinde tanımıştır. Ne var ki, SSCB dağıldıktan sonra yeni bağımsız olan devletler görece bir boşluğa düşmüştür. Çünkü daha öncesinde aralarındaki ilişkileri kontrol eden SSCB artık yoktur. 1991'de bu devletler bir toplantı düzenleyerek, aralarındaki ilişkileri düzenleyecek yeni bir oluşum için irade göstermiştir. Bu amaçla Beyaz Rusya'nın başkenti Minsk şehrinde bir araya gelen Rusya Federasyonu, Belarusya ve Ukrayna devlet başkanları, Bağımsız Devletler Topluluğu'nu kurmuştur. Buna karşılık Kazakistan ve Orta Asya'nın diğer ülke liderleri de Aşkabat'ta bir oluşum için toplanmıştır. Daha sonrasında iki grup Almatı'da toplanarak Almatı Deklarasyonu'nu yayınlamış ve 21 Aralık 1991 'de Bağımsız Devletler Topluluğu çatısı altında birleştiklerini ilan etmişlerdir. Kısa süre sonra SSCB'nin diğer eski üye ülkeleri de bu topluluğa katılma kararı almıştır. Kazakistan 2 Mart 1992'de de Birleşmiş Milletler tarafından üyeliğe kabul edilmiştir. ${ }^{58}$

Sonuç olarak Kazakistan SSCB'nin dağıldığı bir ortamda hızlı refleksler vererek bağımsızlığını kazanmış ve aynı sürati bağımsızlığını uzun vadede devam ettirecek uluslararası atılımlarla da desteklemiştir. Kazakistan Uluslararası sahada kendini kabul ettirdikten sonra da iç politikasına yönelerek bir ulus inşa sürecine girmiştir.

\subsection{ULUS İNŞA ÇABALARI}

Kazakistan 16 Aralık 1991'de bağımsızlı̆̆ını ilan etmiştir. ${ }^{59}$ Her bağımsız devlet gibi Kazakistan da bundan sonra ulus inşası çalışmalarına başlamış ve bir ulus devlet yaratmak adına öncelikle kendi siyasi yapılanmasını bunu başaracağına inandığı yönde tesis etmiş ve sonrasında da Kazak ülkesini ilgilendiren her konuda politikalar

\footnotetext{
${ }^{58}$ Abdulvahap Kara, Okan Yeşilot, a.g.e., s. 42-43.

59 Suale Baycaun, "Bağımsızlıtan Günümüze Kazakistan İç Politikası ve Demokrasi Yolundaki Gelişmeler”, Avrasya Dosyası-Kazakistan-Kırgızistan Özel, Cilt 7/4, 2001-2002, s.72.
} 
geliştirerek amacını gerçekleştirmeye çalışmıştır. Bunu yaparken ise ülkesinde, SSCB döneminde tesis edilen ve bağımsızlığına gölge düşüren pek çok kurum, inançlar sistemi, dil, Kazakların aleyhine seyreden Rusya eliyle oluşturulmuş suni demografik yapı, halen süren Rus güdümlü sanayi ve ekonomi, kısacası Rus asimile çabalarının tüm kalıntıları Kazakistan'ın ulus inşa sürecinde aşması gereken en önemli amiller olarak karşısında duruyordu.

Sovyet asimilasyonlarının Kazak ülkesindeki derin mirası, bağımsızlık sonrası Kazakistan'da bir ulus inşasının sağlanabilmesinin önündeki engeller olarak dururken, aynı zamanda da ulus inşasının itici birer unsurları da olmuştur. Çünkü ulus devlete aykırı düşen miras aşılmadıkça gerçek bir bağımsızlıktan ve milli beraberlikten bahsetmek güçtür. Bu süreci iyi anlayan Kazakistan'da öncelikle yapılacak reformlara karar verecek-süreci yönetecek istikrarlı bir siyasi otorite gerekiyordu. Bu maksatla 1 Aralık 1991'de yapılan referandum ile Kazakistan'da başkanlık sistemine geçildi ve Devlet Başkanı olarak Nazarbayev seçildi. ${ }^{60}$ Bağımsız Kazakistan'ın ilk anayasası 1993 yılında kabul edilmiş ve bu anayasa daha sonra üç kez değişikliğe uğratılmıştır. Özellikle 1995 yılında kabul edilen anayasa, Kazakistan'ın siyasal rejiminin oluşmasında belirleyici bir rol oynamıştır. Bu anayasa, Kazakistan'ın siyasal sistemini, laik, demokratik, sosyal ve hukuk devleti olarak tanımlamaktadır. Halkının tüm hak ve özgürlüklerini teminat altına alan anayasanın 40. maddesi devletin başı olarak başkanı saymaktadır. Başkan bütün iç ve dış politikayı belirleme, yürütme ve ülkeyi dışarıya karşı temsil etme yetkisine sahiptir. Bu ise bağımsız Kazakistan'da otoriter bir yönetimin tesis edildiği anlamına gelmektedir. ${ }^{61}$ Kazakistan'daki bu siyasi yapı, bağımsızlıktan sonraki 10 yıl içinde de değişmemiştir. Bağımsızlı̆̆ının 10. yıl kutlamalarında Cumhurbaşkanı Nazarbayev'in yaptığı konuşma, onun, otoriter rejimlerin anti-demokratikliği konusundaki eleştirilere çok fazla kulak asmadığını göstermektedir.

\section{“Bağımsızlık sürecinde demokrasiyi kullanımının öğrenilmesi gereken bir araç olarak değil, tapinılması gereken bir put olarak görüyorduk. Kendi özelliklerimiz dikkate alınmaksızın dış devletlere özenmeye çalışıllyorduk. Fakat her ülke kendi özelliklerini dikkate alarak demokrasi yolunu izlemelidir."}

Yine de Batılı uzmanların Nazarbayev yönetimini, siyasi reformlar konusunda diğer Orta Asya yönetimlerinden daha az insan hakları ihlali yapan bir yönetim olarak tanımlamaları da dikkat çekicidir. ${ }^{62}$

Kazakistan ulus inşa sürecine önce Sovyet dil mirasını silme çabalarıyla başlamıştır. Kazakistan Komünist Partisi Başkanı Nursultan Nazarbayev öncülüğünde Kazakçanın halk arasında ve eğitim kurumlarındaki etkinliğini artırmak için 21 Ekim 1989 tarihinde Kazak Dili Kurumu ve 1992 tarihinde Uluslararası Kazak Dili Kurumu kurulmuştur. Bu süreç 22 Eylül 1989 tarihinde Kazakistan Komünist Partisi Başkanı

\footnotetext{
${ }^{60}$ Suale Baycaun, a.g.e., s. 72.

${ }^{61}$ Fahri Türk (2012), "Kazakistan'da Değişim Sürecinde Ortaya Çıkan Siyasal Partiler Ve Hareketler", Hukuk ve İktisat Araştırmaları Dergisi, Cilt 4, (2), s. 13.

${ }^{62}$ Saule Baycaun, a.g.e., s. 74-80.
} 
Nursultan Nazarbayev'in çalışmalarıyla Rusça resmi dili yanında Kazakçanın "devlet dili" olarak kabul edilmesiyle devam ettirilmiştir. Kazak anayasasının "Dil Kanunu'nun medya araçları ile ilgili 18/2 maddesinde: “Devlet dilinin kullanılması amacı doğrultusunda mülkiyet şekline bakılmaksızın televizyon ve radyo yayınlarında devlet dilindeki yayınların hacmi, zamanı ve süresi açısından başka dillerde verilen haberlerin toplamından az olmamalıdır" şeklindeki ibareyle de medyanın da Kazakçanın etkililiğini artırmak için etkin bir biçimde kullanılmak istendiğini göstermektedir. Fakat yine de resmi dilin Rusça olması ortak bir dil kültürünün gelişmesini engellemiştir. ${ }^{63}$

SSCB'nin dilden başka, Kazak tarih ve kültür öğeleriyle oynadığg ifade etmiştik. İşte Kazakistan'da dilden sonra bu konuya eğilmiş ve SSCB'nin bu mirasını da silme gayreti göstermiştir. Özellikle de Kazak ulusal kimliğine hem bir ortak bellek yaratmak hem de meşruiyet kaynağı sağlamak adına yeni tarih yazımı politikaları benimsenmiştir. Bu bağlamda, öncelikli olarak 1991 yılında hükümete bağlı olarak kurulan "Kazak Eğitim Akademisi" tarafından tarih ders kitapları kapsamlı değişikliğe uğratılmıştır. 1995 yılında ise, Kazakistan Devlet Başkanı Nazarbayev'in yönetimindeki Devlet Politikası Milli Kurulu'nca "Kazakistan Cumhuriyeti Tarih Bilincini Kurma Belgesi" oluşturulmuştur. ${ }^{64}$ Kazakistan Cumhuriyeti Tarih Bilincini Kurma Belgesi'ne göre Kazak tarihçiliği, anayurt ve ata mitleri üzerinden şekillendirilmeye çalışılmıştır. ${ }^{65}$ Artık bağımsız Kazakistan tarih yazımında Kazak devleti, "Antik çağlardan beri Kazak topraklarında var olan büyük göçer imparatorlukların ve kağanlıkların devamı" şeklinde ele alınmıştır. Aynı zamanda bu yeni tarih yazımında, SSCB tarih yazımında dışlanan bir unsur olan göçerlik, Türk medeniyetinin kaynağ 1 olarak yüceltilmiş ve Kazakların kökenlerinin ezel ve ebed olduğu vurgusu yapılmıştır. Yapılan arkeolojik çalışmalar da artırılarak, bulunan kalıntılar, yeni Kazak milli tarih yazıcılığının söylemlerini desteklemek için kullanılmıştır. Yine bir ulusa altın çağını yaşatan kahraman mitlerin, ulus inşa sürecindeki önemini kavrayan bağımsız Kazak Devleti, tarihini, Aakalar, Moğollar ve Göktürkler'e referansla oluşturulmaya çalışılmıştır. Örneğin Kazak Hanlığının kurucuları Kerei ve Janibek Hanlar (1465-1480), Çarlık Rusya'sı ve Çin'in çift yönlü baskısına direnmeye çalışan Abılay Han (1771-1781) ve Kazak Hanlığının Çarlık Rusya'sı egemenliği altındaki döneminden, 1847 yılındaki ölümüne kadar Rus güçleriyle savaşan Kenesarı Han (1841-1847), ata miti bağlamında sunulmakta ve kahramanlaştırılmaktadır. ${ }^{66}$ Geçmiş tarihten mit oluşturma yanında Kazakistan'ın bağımsızlı̆ıyla özdeşleştirilen Devlet Başkanı Nazarbayev de "Kurucu Baba" ve ulusun sembolü olarak Kazak tarihine sunulur. Bu tarih yazımı somut olarak

\footnotetext{
${ }^{63}$ Ayşe Kara, "SSCB Sonrası Coğrafyada Ulus İnşa Süreci: Kazakistan Örneği”, Alternatif Politika Dergisi, Cilt. 4, Sayı. 3, 2012, s. 366-367.

${ }^{64}$ Utku Yapıcı, , Sovyet Sonrası Coğrafyada Devlet ve Milliyetçilik: Estonya, Ukrayna ve Kazakistan Örnekleri, Yayımlanmamış Doktora Tezi, Ankara Üniversitesi Sosyal Bilimler Enstitüsü, 2009, s. 11-12-1314.

${ }^{65}$ Kadir Ertaç Çelik, Kimlikler Güç Dengesi ve İttifaklar: Kazakistan Örneği, Yükseklisans Tezi, Gazi Üniversitesi Sosyal Bilimler Enstitüsü, 2014, s. 67.

${ }^{66}$ Utku Yapıcı, a.g.e., s. 11-14.
} 
heykellerde can bulmuştur. Kazakistan'da şehrin önemli merkezlerinde mit heykellerin halkın gözünün önünde olması sağlanmıştır. Örneğin, Kazakistan'ın başkenti Astana'da birçok meydanda Nazarbayev heykeli yer almaktadır. Aynı zamanda yine başkent Astana'da bulunan Bayterek anıtında Nazarbayev'in sağ eli resmedilmiş ve bu ele dokunulduğunda milli marş çalmaktadır. ${ }^{67}$

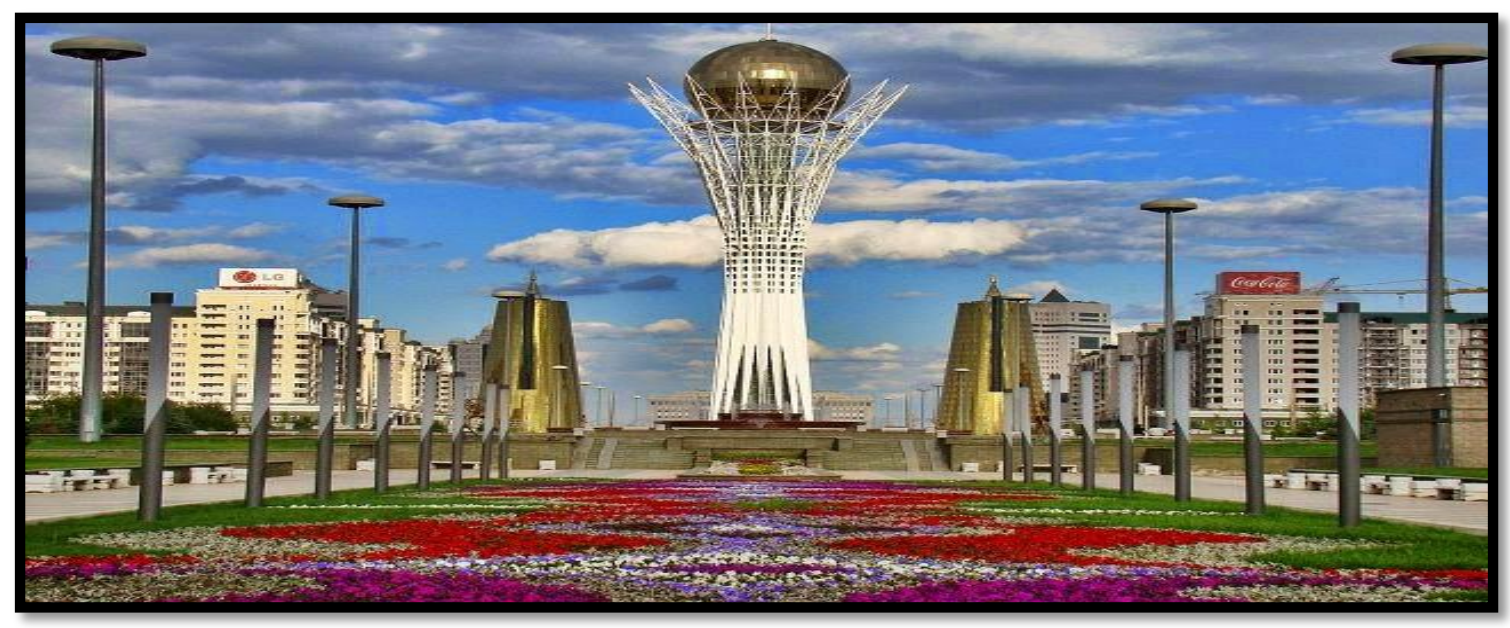

Şekil 2. Kazakistan'ın Astana Şehrinde Bulunan Bayterek Anıt

Bayraklar, devlet arması, milli marş, üniformalar, haritalar, mimari vb. gibi unsurlar ortak algı oluşturması bakımından ulus inşa sürecinde kullanılan önemli sembollerdir ${ }^{68}$ Kazakistan da bağımsızlığını ilan ettikten sonra ulusal bayrak, ulusal marş, devlet arması gibi ulusal kimliği belirten unsurlara yönelmiştir. Bu bağlamda, 11 Aralık 1992 yılında ulusal bayrak yapılmış ve milli marş yazılmıştır. Bayrak, "ulusu evrenselleştiren, onun uluslararası dünyadaki rolünü simgeleyen, ölümsüzlügünü gösteren hatta vaat eden, dolayısıyla da aidiyeti kavranır kılan ve bireyleri o kolektif kimliğe taşıyan somut göstergelerden biridir. ${ }^{69}$ Kazakistan milli bayrağında da bu göstergelerin somutlaştı̆̆ı görülmektedir. Bağımsız Kazakistan milli bayrağındaki mavi rengin "Gök Tanrı" inancıyla ilgili olduğu anlaşılmaktadır. ${ }^{70}$ Yine bağımsızlığın en önemli sembolü olan milli para birimi tene Kazakistan'da 15 Kasım 1993’te kabul edilmiştir. ${ }^{71}$

\footnotetext{
${ }^{67}$ Ayşe Kara, a.g.e., s. 369.

68 Serpil Aydos, Türkiye'nin Tanıtım Filmlerinde Ulusal Kimlik Anlatısı, Ankara Üniversitesi Sosyal Bilimler Enstitüsü Yayımlanmamış Doktora Tezi, 2009, s. 47.

${ }^{69}$ İsmet Parlak(Derleyen), Yazılı Basında Mit'in Tekrarı ve İçe Sallanan Bayrak, Medyada Gerçekliğin İnşası: Türk Medya Söylemine Eleştirel Bir Bakış, 1. Basım, Çizgi Kitabevi, Konya 2009, s. 245.

${ }^{70}$ Şahin Küçük, “Eski Türk Kültüründe Renk Kavramı”, Bilig, 2010, Sayı 54, s. 195.

${ }^{71}$ Abdulvahap Kara, Okan Yeşilot, a.g.e., s. 44.
} 


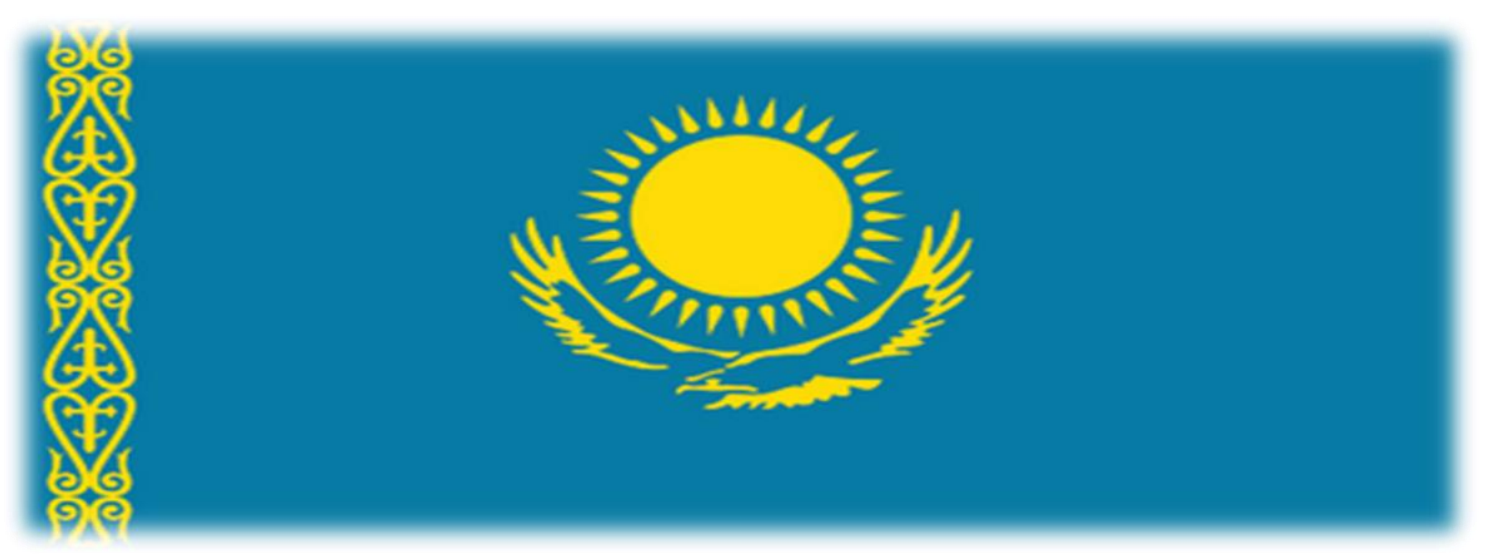

Şekil 3. Kazakistan Ulusal Bayrağ1

\section{KAZAKŞA}

Altun kün aspanı, Altın dän dalası, Erliktiñ dastanıElime qarașı!

Ejelden er degen, Dañqımız şıqtı ğoy, Namism bermegen, Qažğım mıqtı ğoy!

Qayrması:

Meniñ elim, meniñ elim, Güliñ bolıp egilemin, Jırıñ bolıp tögilemin, elim!

Tuvğan jerim meniñ - Quzaqstanım

Urpaqqa jol așqan,

Keñ baytaq jerim bar.

Birligi jarasqan,

Tävelsiz elim bar.

Qarsı alğan vaq̣ıttı, Măñgilik dosinday.

Bizdiñ el baqtth, Bizdiñ el osınday!

\section{TÜRKÇE}

Altın günę̧ seması

Altın başak bozkırn

Yiğitliğin destanı

C̈lkeme baksana!

Ezelden er diye, Şanımız çıkmıştır, Hiç boyun eğmeyen, Kazağım güçlüdür.

Nakarat:

Benim ülkem, benim ülkem, Gülün olur ekilirim, Şiiirin olur dökülürüm, ülkem! Vatanım benim - Kazakistanım

Nesillere yol açan,

Çok geniş ülkem var, Birliği sağlam,

Bağımsız devletim var.

Karșılayan zamamı

Ebedi dostu gibi,

Bizim ūlkemiz mutlu,

Bizim ūlkemiz iştł bu.

Şekil 4. Kazakistan Ulusal Marşı ve Türkçe Manası,

Kaynak: http://www.abdulvahapkara.com/kazak-milli-mar-ceviri-denemesi/ 


\subsection{ULUS INNŞA SÜRECINDE KAZAKİSTAN'IN EKONOMI POLITIGĞİ}

Bağımsızlık öncesi Kazakistan, Sovyet ekonomisine tarım ürünleri ve hammadde ihtiyacı alanlarında hizmet eden bir ülke görünümündedir. Bu manada Kazakistan, bağımsızlık sonrasında kendisini Sovyetler döneminde inşa edilmiş eski sanayi tesisleriyle baş başa bulmuştur. Böylece bu sanayi tesislerinin, ulus inşa sürecinin ekonomik boyutu açısından, yeni ekonomi politikalarına uygun olarak işletilmesi konusu Kazakistan'ın karşısında durmuştur. ${ }^{72}$ Fakat tarım ve hayvancılıkla geçimini sağlayan Kazaklar, bağımsızlık sonrası süreçte ağır sanayiye ilgisiz kalmıs ve bu kuruluşlar artık iş göremez hale gelmeye başlamıştır. Çağın gerçekleri ise sanayisi işlemeyen aktörlere uluslararası sahada uzun süreli varolma şansı tanımıyordu. Bu gerçekliği iyi analiz eden Nazarbayev, bu problemlerin ortadan kaldırılması, iç ve dış pazarın oluşturulması, zengin yeraltı kaynaklarının ülke içinde işletilmesi, serbest pazar ekonomisine geçiş gibi amaçlarla piyasalar üzerindeki hükümet kontrolünü ortadan kaldırmaya ve devlet işletmelerini özelleştirmeye yönelik ekonomik reform politikalarını devreye sokmuştur. Bu reformlar; liberal ticaretin tesisi, fiyat politikaları, yatırımların teşviki kanununun çıkarılması, vergi ve gümrük konuları üzerine odaklanmıştır. Bu süreçteki en büyük atılımlardan biri de, ekonomik bağımsızlığın mihenk taşı olan para biriminin millileştirilmesi olmuştur. Kazakistan, 15 Kasım 1993 'te milli para birimi Tenge'yi tedavüle sokmuştur. Aynı yıl, özelleştirme programı tanıtılmaya başlanmış ve özel sektörün ticari faaliyetleri için yasal düzenlemeler yapılmıştır. Sovyetlerin dağılmasının yarattığı kaotik ortamda Kazakistan, dış politikasında, stratejik doğal kaynaklarını ve nükleer gücünü ön plana atmıştır. Bu başarılı politikalar sayesinde 1994 'te, Batı' dan 1 milyar dolar kredi alabilmiştir. ${ }^{73}$ Reform çabaları sonucunda Kazakistan ekonomisinde büyük oranda ticari liberalizasyonun sağlandığı, tekel kurumların tasfiyesi edildiği, ticaret ve bankacılık sektörünün geliştiği görülmektedir. ${ }^{74}$

Kazakistan'ın bağımsızlık tarihinin 2017 yılına olan uzaklığı, devletlerin ömrü açısından kısa bir süreyi teşkil eder. Kazakistan bağımsızlığının ilk yıllarından itibaren bünyesinde barındırdığı Sovyet sanayi altyapısı ve ulus inşa sürecinde gösterdiği başarılı ekonomi politik hamleleriyle birçok devletin ilgisini çekmiştir. Pek çok aktör, Kazakistan'ın sanayi tesislerini modernize ederek buradan çıkar sağlamak adına Kazakistan'a değişik tutarlarda yatırım ve yardım talepleriyle gelmişlerdir. ${ }^{75}$ Kazakistan Devleti ise bu süreçte, tahayyül ettiği ulus inşası açısından, ulusal çıkarına uygun teklifleri kabul etmek suretiyle birçok bağıta imza atmıştır. Bu gelişmeler sonucunda Avrupa ve ABD, Kazakistan'1 BDT'nin tek "piyasa ekonomisi" olarak adlandırılmaya başlamış ${ }^{76}$ ve dünya kredilendirme kuruluşları Kazakistan'ın kredi

\footnotetext{
${ }^{72}$ Abdulvahap Kara, Okan Yeşilot, a.g.e., s. 116.

${ }^{73}$ Abdulvahap Kara, Okan Yeşilot, a.g.e., s. 118-120.

${ }^{74}$ Mehmet Dikkaya, Ali Bora, “Çağdaş Kazakistan'ın Ekonomi Politiği ve Türkiye'nin Yeri”, OAKA, Cilt 1, Sayı 2, 2006, s. 111.

75 Ayhan Gençler, Recep Seymen, Arif Akbaş, "Kazakistan'ın Emek Piyasasına Güncel Bir Bakış", Uluslararası Insan Bilimleri Dergisi, Cilt 9, Sayı 1, 2012, s. 323.

${ }^{76}$ Mehmet Dikkaya, Ali Bora, a.g.e., s. 111.
} 
notu, BBB'ye yükseltmiştir. Kazakistan'da 2000-2007 arasındaki GSYİH'nın reel büyüme oranı \%10 civarıda seyretmiştir. 2007 yılında, bu oran \%8,7'lik artış göstermiştir. Hatırı sayılır bu ekonomik büyüme sonucunda 2007 'de üretim hacmi; sanayi sektöründe $\% 4,5$, tarım sektöründe $\% 8,5$, ticarette $\% 10$, taşımacılık sektöründe ise \%4,7 oranında artış göstermiştir. ${ }^{77}$ Burada belirtmek gerekir ki reformlar ekonomide ne kadar müspet sonuçlar vermişse de Kazak halkının bir kısmında (Mülksüzler) özellikle batıyla olan yakınlaşma olmak üzere, bölgelere ve kişilere göre olan adaletsiz gelir dağılımından duyulan hoşnutsuzluk yükselmiştir ve bu kesim Sovyet komünizmini arzulamaya başlamıştır. ${ }^{78} \mathrm{Bu}$ ise reformun hassas sosyal politikalarla gerçekleştirilmesi gerekliliğini bir kez daha gözler önüne sermiştir.

Tablo 1. Kazakistan Ekonomisinin Yıllara Göre Temel Ekonomik Göstergeleri

\begin{tabular}{|l|c|c|c|c|}
\hline & $\mathbf{2 0 0 4}$ & $\mathbf{2 0 0 5}$ & $\mathbf{2 0 0 6}$ & $\mathbf{2 0 0 7}$ \\
\hline GSYİH (milyar dolar) & 43,2 & 56,1 & 76,8 & 103,8 \\
\hline GSYİH Büyüme Oranı ( \% ) & 9,4 & 9,4 & 10,6 & 8,5 \\
\hline Enflasyon Oranı (TÜFE \%) & 6,9 & 7,6 & 8,6 & 10,8 \\
\hline İhracat (milyar dolar) & 20,6 & 26,2 & 41,2 & 48,3 \\
\hline İthalat (milyar dolar) & 13,8 & 16,3 & 24,6 & 33,2 \\
\hline Cari İşlemler Dengesi (GSYİH'ya Oranı \%) & 335 & -1.056 & -1.797 & $-4,643$ \\
\hline Dış Borç (milyar dolar) & 31,9 & 44,0 & 77,2 & 96,3 \\
\hline Döviz Kuru (ort., 1 ABD doları: Tenge) & 136,04 & 132,88 & 126,09 & 122,55 \\
\hline
\end{tabular}

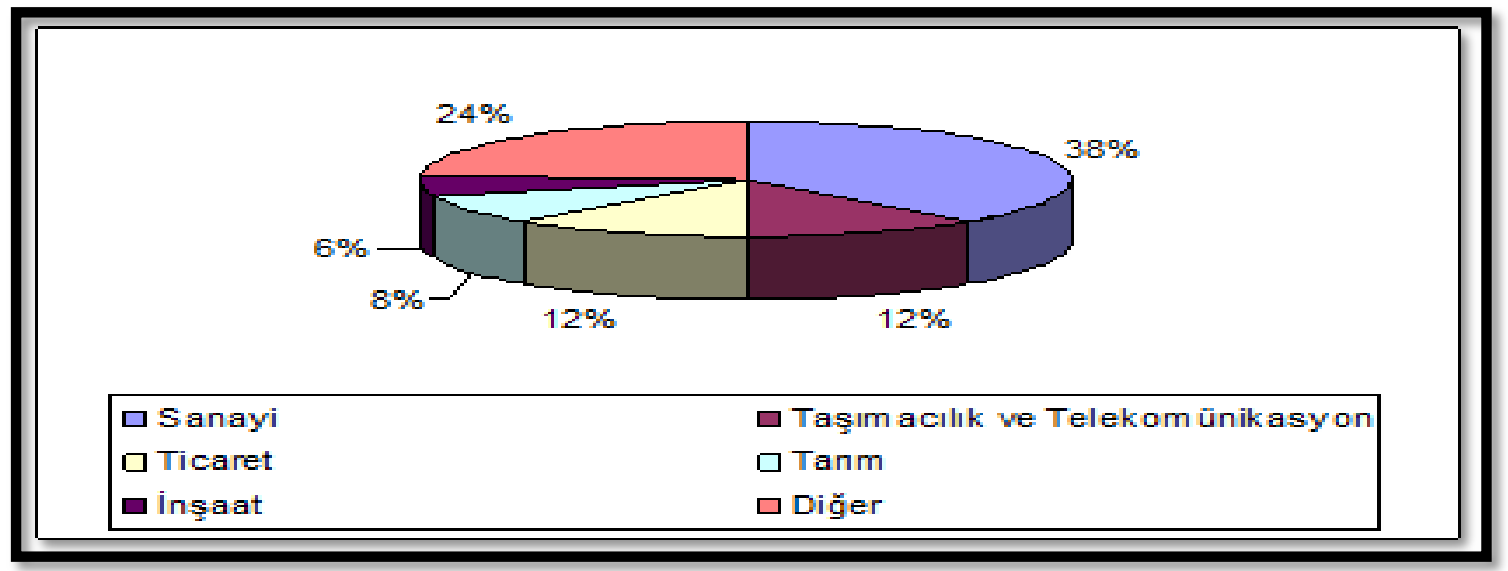

Şekil 5. Ülke GSYİH'sinin Sektörel Dağılımı

\footnotetext{
${ }_{77}$ Abdulvahap Kara, Okan Yeşilot, a.g.e., s. 120.

${ }^{78}$ Joma Nazpary, Sovyet Sonrası Karmaşa Kazakistan'da Şiddet ve Mülksüzleşme, 1. Baskı, İletişim Yayınları, İstanbul 2003, s. 106.
} 
Tablo 2. Kazakistan'ın Yıllara Göre İthalat-İhracat ve Dış Ticaret Hacmi

\begin{tabular}{|l|c|c|c|c|c|c|c|c|}
\hline & $\mathbf{2 0 0 0}$ & $\mathbf{2 0 0 1}$ & $\mathbf{2 0 0 2}$ & $\mathbf{2 0 0 3}$ & $\mathbf{2 0 0 4}$ & $\mathbf{2 0 0 5}$ & $\mathbf{2 0 0 6}$ & $\mathbf{2 0 0 7}$ \\
\hline İhracat & 9,28 & 9,02 & 9,70 & 12,90 & 20,09 & 27,84 & 38,20 & 48,35 \\
\hline İthalat & 6,84 & 7,84 & 6,49 & 8,32 & 12,78 & 17,35 & 23,60 & 33,21 \\
\hline Diş Ticaret Hacmi & 16,12 & 16,86 & 16,19 & 21,22 & 32,87 & 45,19 & 61,80 & 81,56 \\
\hline Diş Ticaret Dengesi & 2,44 & 1,18 & 3,21 & 4,58 & 7,31 & 10,49 & 14,60 & 15,14 \\
\hline
\end{tabular}

Tablo 3. Kazakistan'ın Dış Ticarette Başlıca Ortakları (2006)

\begin{tabular}{|l|c|l|c|}
\hline İTHALAT & $\mathbf{\%}$ & IHRACAT & $\mathbf{\%}$ \\
\hline İtalya & 18,0 & Rusya & 38,3 \\
\hline İsviçre & 17,6 & Çin & 8,1 \\
\hline Rusya & 9,8 & Almanya & 7,7 \\
\hline Çin & 9,4 & ABD & 4,7 \\
\hline Fransa & 8,8 & Ukrayna & 4,2 \\
\hline
\end{tabular}

Kaynak: The Economist Intelligence Unit, 2 Haziran 2008

Kazakistan, özellikle 2000'li yıllardan itibaren ekonomi politikalarında müdahaleci stratejiler izlemiştir. Kazak hükümetinin bu dönemki ekonomi politiğinin temel amacl: Ekonominin enerji dişındaki sektörlerini kalkındırarak ekonomide çeşitlilik sağlamak ve ekonominin petrol fiyatlarına bağlılığını kırmaktır. Bu amaçla hazırlanan, 2003-2015 dönemini kapsayan "Endüstriyel Yenilenme ve Kalkınma Programı" ile Kazakistan, GSYİH'sindeki büyümeyi, yıllık bazda \%8'in üzerinde tutmayı ve ekonomik çeşitliliği hedeflenmektedir. Program dahilinde; turizm, petrol ve doğalgaz ekipmanı, gıda, tekstil, taşımacılık ve lojistik sektörleri öncelikli sektörler olarak belirlenmiş ve yeni teknolojiler kullanılarak bu alanlarda projeler geliştirilmeye ve hayata geçirilmeye başlanmıştır. Kazakistan ekonomisinde son yıllarda GSYİH içinde hizmet sektörünün payının giderek arttığ görülmektedir. Bu ise beraberinde, ekonomide dışa açılmayı getirmektedir. Bu çerçevede de Kazakistan'nın, geleneksel ticari ortaklarının yanında $A B D$ ve Türkiye ile de sıcak ekonomi ilişkiler kurduğu görülmektedir. Yine de belirtmek gerekir ki Kazakistan bağımsızlığından beri diş ekonomik ilişkilerinde Rusya'yı hep daha ön planda tutmaktadır. Bu ise petrollerini dünya pazarlarına ulaştırmak için Rusya'ya olan bağımlılı̆̆ından ileri gelmektedir. ${ }^{79}$ Kazakistan mallarının önemli alıcıları arasında sırasıyla; Rusya Federasyonu $(\% 15,7)$, Çin $(\% 10,5)$, İsviçre $(\% 8,1)$, B.A.E. $(\% 4,9)$, Polonya $(\% 3,3)$, İran $(\% 3,2)$, Ukrayna (\%3), Almanya (\%2,3), Büyük Britanya (\%1,4), Hollanda (\%1,3), ABD (\%1,2) ve Özbekistan $(\% 1,1)$ bulunmaktadır. 2002'de, BDT ülkelerinin brüt ithalattaki payı \%46,7 olmuştur (200 1 'de \%52). İthalatın gerçekleştirildiği ülkeler arasında ise; Rusya Federasyonu (\%3 $9,1)$, Almanya $(\% 8,7)$, ABD (\%7), Çin (\%4,7), Büyük Britanya $(\% 3,9)$, İtalya ve Ukrayna (\%3'er), Türkiye $(\% 2,6)$, Japonya $(\% 2,5)$, Güney Kore ve Fransa $(\% 1,7)$, Özbekistan ve Hollanda $(\% 1,3)$ bulunmaktadır. Ağırlıklı olarak zengin yeraltı kaynaklarından gücünü alan Kazakistan ekonomisi, bağımsızlığının ilk yıllarında 1500 dolar olan kişi başına

\footnotetext{
${ }^{79}$ Abdulvahap Kara, Okan Yeşilot, a.g.e., s. 122-127.
} 
düşen milli gelirini, izlediği başarılı ekonomi politik ile 2015 yılında 12 bin doların üzerine çıkarmış bulunmaktadır. ${ }^{80}$ Günümüzde de Kazakistan bu istikarını sürdürmektedir ve pek çok bilimsel çalışmada Kazakistan'ın ekonomik büyümesi kastedilerek, bu ülke için, "Bağımsız Devletler Topluluğunun Parlayan Yıldızı" betimlemesi yapilmaktadır.

Kazakistan, uluslararası sahada olumlu imaj çizerek, ekonomi politikalarını bu yolla da desteklemektedir. Bu bilgiye güncel bir örnek olarak; 2016'da Antalya'da gerçekleştirilen EXPO'nun, önümüzdeki aylarda (10 Haziran-10Eylül 2017) EXPO 2017 adıyla Kazakistan'da yapılacağı kesinleşmiştir. Kazakistan'ın fuara ilişkin teması “Geleceğin Enerjisi"'dir. Tüm dünyanın ilgisini çeken bu tarz organizasyonlar Kazakistan'ın ekonomik, kültürel potansiyelinin tanınmasında önemli rol oynarken ev sahibi ülkelere çeşitli alanlarda ekonomik gelirler sağlamaktadır. Bunu iyi gören Nazarbayev EXPO 2017'ye ev sahibi yapacak olmakla alakalı şu tespitlerde bulunmuştur.

"Bu neyi gösterir? İlk olarak bu tüm dünyanın ülkemizi iyi bildiğini gösterir. İkincisi Astana şehrimizin böylesine geniş çaplı bir organizasyonu gerçekleştirecek tüm imkanlara sahip olduğunu gösterir. Bu kolay bir iş değildir. Biz bunun için ter döktük. Çok çalıştık. Bu 20 yıl boyunca yaptığımız başarılı işlerinin sonucu, Kazakistan'ın gelişmesinin, dünyada saygın bir yeri olduğunun bir göstergesidir. Bunun sevinilecek bir durum olduğunu söyleyebilirim." 81

\section{SONUÇ VE ÖNERILER}

Kazakistan ekonomisi, bağımsızlığın ilk yıllarından itibaren yavaş fakat istikrarlı bir büyüme sürecine girmiştir. 2017 itibariyle de Kazakistan ekonomisi daha çeşitli alanlarda, hızlı, anlamlı bir istikrar içerisindedir.

Tarım ve hayvancılığa yatkın olan Kazak halkı, bağımsızlıkla beraber kendisini, teknik bilgisinin az olduğu Sovyet sanayi ile karşı karşıya bulmuştur. Eğer ülkede etkin bir liberal ekonomi modeli oturtulmak isteniyorsa Kazak iş̧̧i gücü, modern sanayinin gerektirdiği kalifiyeye ulaştırılmalı ve çalışma ile ilgili yönetmeliklerin dünya standartlarına uygun şekilde revizyona uğratılması gerekmektedir.

Kazakistan, Rusya yanında, yeni ekonomik ortaklıklar kurmak yoluyla dünya ticaretinde varlığını hissettirmektedir. Bu ise Kazakistan ekonomisini bağımlılıktan kurtarmakta ve Kazakistan'a dengeleme aktörleri yaratmaktadır. Kazakistan'ın diş politikasında yarattığı bu denge, hem ulusal çıkarlarını sağlamada hem kendi halkı içerisinde kimi kesimlerin potansiyel devrimci hareketlerini önlemede etkili olabilir.

İkili ekonomik ilişkilerin yanı sıra, Orta Asya ülkeleri arasında kurulan kolektif yapılanmaların, Kazakistan'ın dengeleme politikasına ek bir hareket sahası kazandırabileceği ve Avrasya enerji kaynaklarının güvenliği açısından önemli olduğu

\footnotetext{
${ }^{80}$ M. Said Ceyhan, Ahmet Akpolat, Mehmet Akif Peçe, “Kazakistan Ekonomisinin Dişa Açıklık ve Enflasyon Oranlarının Ekonomik Büyümesine Etkisi (1994-2013)", International Journal of Cultural and Social Studies, Cilt 2, Sayı 1, 2016, s. 47.

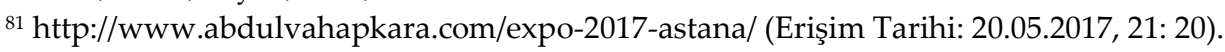


unutulmamalıdır. Bu manada bu tarz yapılanmaların aktif olarak varlık gösterebilmesi için Kazakistan öncülük yapmalıdır.

Kazakistan, hem nükleer gücünü hem de "Yeşil Gücü"nü, ekonomi politikalarında etkili olarak kullanmaktadır.

Bağımsızlıktan sonra Kazakistan'da etnikten kaynaklanan olayların sıfıra yakın seyretmesi, Rusya ile olan karşılıklı bağımlılık ve Nazarbayev'in hoşgörülü siyasetinden kaynaklanmakta olduğu görülmektedir. Bu şartlardan biri değiştiğinde ulus inşa sürecinin ve dolayısıyla ekonomik gelişmenin tehlikeye düşeceği unutulmamalıdır.

Kazakistan ekonomi politikaları, bölgelere göre büyük farklılıklar göstermektedir. Bu durum adaletsiz gelir dağılımını beraberinde getirmektedir. Bu ise ulus inşa süreci açısından riskli sonuçlar doğurabilir.

Doğal kaynaklarının zenginliği nedeniyle yoğun göç alan Kazakistan, göçmenlerin ülkeye alınmasında daha seçici politikalar izlemelidir. Kazakistan bu yolla hem kaynakların verimli kullanılmasını hem de ülkeye göçmenlerle gelebilecek çeşitli problemleri engelleyebilir.

\section{KAYNAKÇA}

Al, A. (2015). Politika-Ekonomi Kesişmesi: Yeni Bir Bilim Dalı Olarak Uluslararası Politik Ekonomi, İstanbul Gelişim Üniversitesi Sosyal Bilimler Dergisi, 2 (1): 143-159.

Aralbekov, N. (2016). Kazakistan Etnik Denge Siyasetinin Temeli Olarak Kazakistan Halk Asamblesi, Gazi Üniversitesi Sosyal Bilimler Enstitüsü, Yüksek Lisans Tezi, Ankara, VII-84.

Ateş, D., Gökmen, G. S. (2013). “Bir Akademik Disiplin Olarak Uluslararası Politik Ekonominin Sınırları", Afyon Kocatepe Üniversitesi Sosyal Bilimler Dergisi, 15 (1): 45-71.

Aydos, S. (2009). Türkiye'nin Tanıtım Filmlerinde Ulusal Kimlik Anlatısı, Ankara Üniversitesi Sosyal Bilimler Enstitüsü, Yayımlanmamış Doktora Tezi, Ankara, V+254.

Ceyhan, M. S., Akpolat, A., Peçe, M. A. (2016). Kazakistan Ekonomisinin Dışa Açıklık ve Enflasyon Oranlarının Ekonomik Büyümesine Etkisi (1994-2013), International Journal of Cultural and Social Studies, 2 (1): 45-61.

Çam, S. http://www.tuicakademi.org/etnisite-kavrami/ (E.T. 05.04.2017, 16:20).

Çavuşoğlu, N. Azınlık Nedir, İnsan Hakları Yıllı̆̆̆, Cilt 19-20, 1997-1998:93-101.

Çelik, K. E. (2014). Kimlikler, Güç Dengesi ve İttifaklar: Kazakistan Örneği, Gazi Üniversitesi Sosyal Bilimler Enstitüsü, Yükseklisans Tezi, Ankara, Xİ+119.

Dikkaya, M., Bora, A. (2006). Çağdaş Kazakistan'ın Ekonomi Politiği ve Türkiye'nin Yeri, OAKA Dergisi, 1 (2): 110-127.

Gençler, A., Seymen, R., Akbaş, A. (2012). Kazakistan'ın Emek Piyasasına Güncel Bir Bakış, Uluslararası İnsan Bilimleri Dergisi, 9 (1): 322-335.

Hizmetli, S. (2011). Kazak Ulusu ve Kazak Tarihi Üzerine: Dünü ve Bugünü, İstem Dergisi, 9 (17): 23-43. 
http://geographicam.blogspot.com.tr/2016/02/kazakistanin-ekonomikcografyasi.html

(E.T. 08.04.2017, 13:44).

Kafkasyalı, M. S. (2012). Bölgesel ve Küresel Politikalarda Orta Asya, Ahmet Yesevi Üniversitesi Yayınları, Ankara-Türkistan, s. 600.

Kara, A. (2017). “Kazakistan'ın Uluslararası Alandaki Yeni Başarısı: EXPO 2017’ye Astana Ev Sahipliği Yapacak", http://www.abdulvahapkara.com/expo-2017-astana/ (E.T. 20.05.2017, 21: 20).

Kara, A., Yeşilot, O. (2011). Avrasya'nın Yükselen Yıldızı Kazakistan, İstanbul Ticaret Odası Yayınları, İstanbul, s. 304.

Karacagil, K. (2014). Kazakistan'ın Bağımsızlığının Ayak Sesleri: Almatı Olayları (1986), History Studies Dergisi, 6 (1): 101-114.

Kolektif (2007). Kazakistan Tarihi Makaleler, Türk Tarih Kurumu Yayınları, Ankara, s. 228.

Kurubaş, E. (2014). Asimilasyondan Tanınmaya Uluslararası Alanda Azınlık Sorunları ve Avrupa Yaklaşımı, 2. Baskı, Asil Yayın Dağıtım, Ankara, s. 315.

Nazarbayev, N. (2000). Yüzyılların Kavşağında, 2. Baskı, Bilig Yayınları, Ankara, s. 271.

Nazpary, J. (2003). Sovyet Sonrası Karmaşa Kazakistan'da Şiddet ve Mülksüzleşme, 1. Baskı, İletişim Yayınları, İstanbul, s.309.

Sağlam, A. (2012). Sovyet Kimliği ve Sürekliliği, http://www.turkdod.com/2012/05/02/sovyetkimligi-ve-surekliligi/ (E.T. 05.05.2017, 13.54).

Saray, M. Rusya'nın Türkistan'da Yayılması, https://www.tarihtarih.com/?Syf=26\&Syz=356235, (E.T. 09.04.2017, 18:41).

Saray, M. (1993) Kazak Türkleri Tarihi: Kazakların Uyanışı, Nesil Matbaacılık ve Yayıncılık, İstanbul, s. 189.

Şener, B. (2014). Küreselleşme Sürecinde Ulus-Devlet ve Egemenlik Olguları, Tarih Okulu Dergisi, 18:51-77.

Velihanov, Ç. (2011). Şığarmalar Jinağı II, Almatı 1985, [Aktaran: Yerkinay Maukhara], Siyasi ve Kültürel Açıdan Kazak Hanlığı (1456-1731), Yüksek Lisans Tezi, Konya, IV+133.

Yalçıner, R. (2014). Etnisite ve Milliyetçilik: Eleştirel Bir Değerlendirme, Ankara Üniversitesi SBF Dergisi, 69 (1):189-215. 